\title{
Article
}

\section{Neanderthal Fossils, Mobile Toolkit and a Hyena Den: The Archaeological Assemblage of Lateral Gallery 1 in Cova Del Gegant (NE Iberian Peninsula)}

\author{
Joan Daura ${ }^{1, *(\mathbb{D} \text {, Montserrat Sanz }}{ }^{1, *}$, Manuel Vaquero ${ }^{2,3}$, Juan Manuel López-García ${ }^{2,3}$ (D), \\ Hugues-Alexandre Blain ${ }^{2,3}{ }^{(1)}$ and Antonio Sánchez Marco ${ }^{4}$ (i) \\ 1 Grup de Recerca del Quaternari (GRQ-SERP), Departament d'Història i Arqueologia, \\ Universitat de Barcelona, Carrer Montalegre 6, 08001 Barcelona, Spain \\ 2 Departament d'Història i Història de l'Art, Universitat Rovira i Virgili (URV), Avinguda de Catalunya 35, \\ 43002 Tarragona, Spain; manuel.vaquero@urv.cat (M.V.); jmlopez@iphes.cat (J.M.L.-G.); \\ hablain@iphes.cat (H.-A.B.) \\ 3 Institut Català de Palaeoecologia Humana i Evolució Social (IPHES-CERCA), Campus Sescelades \\ URV (Edifici W3), Zona Educacional 4, 43007 Tarragona, Spain \\ 4 Institut Català de Palaeontologia Miquel Crusafont, Campus de la UAB, 08193 Bellaterra, Spain; \\ antonio.sanchez@icp.cat \\ * Correspondence: jdaura_lujan@ub.edu (J.D.); montsesanzborras@ub.edu (M.S.)
}

\section{check for}

updates

Citation: Daura, J.; Sanz, M.;

Vaquero, M.; López-García, J.M.;

Blain, H.-A.; Marco, A.S. Neanderthal Fossils, Mobile Toolkit and a Hyena Den: The Archaeological Assemblage of Lateral Gallery 1 in Cova Del Gegant (NE Iberian Peninsula). Quaternary 2022, 5, 12. https:// doi.org/10.3390/quat5010012

Academic Editor: Maria Rita Palombo

Received: 26 July 2021

Accepted: 19 January 2022

Published: 18 February 2022

Publisher's Note: MDPI stays neutral with regard to jurisdictional claims in published maps and institutional affiliations.

Copyright: (C) 2022 by the authors. Licensee MDPI, Basel, Switzerland. This article is an open access article distributed under the terms and conditions of the Creative Commons Attribution (CC BY) license (https:// creativecommons.org/licenses/by/ $4.0 /)$.

\begin{abstract}
Lateral Gallery 1 (GL1) in Cova del Gegant is a Middle Palaeolithic assemblage yielding diagnostic Neanderthal remains, together with Mousterian tools and faunal remains. It is a good archive for evaluating the environmental conditions of the coastal areas during MIS 4 and MIS 3 in the NE of the Iberian Peninsula, and also the Neanderthals' behaviour and mobility. Here we provide a comprehensive assessment of all of the data available from GL1, such as lithics, human remains, fauna and chronostratigraphic details. The biotic ecofacts studied point to the development of a coastal plain in front of the cave and indicate that local conditions likely favoured a large variety of ecosystems characterised by open environments and woodland-edge taxa, and favoured repeated visits by humans during the Middle Palaeolithic. The evidence suggests that the gallery was mainly used by carnivores, such as hyenas, and also by Neanderthals as a brief stopping place, in view of the presence of transported and abandoned ergonomic lithic artifacts and/or the placement of bodies (or parts of bodies). The regional context suggests high human mobility and emphasises the variability of Neanderthal behaviour.
\end{abstract}

Keywords: late Pleistocene; Neanderthals; palaeoenvironment; NE Iberian Peninsula; hyena

\section{Introduction}

Archaeological sites are generally palimpsests, mixing remains from the successive activities of carnivores and humans carried out during their temporary stays. Thus, sites have often lost their individuality (i.e., their stratigraphic resolution or diachrony) and integrity (i.e., their internal organisation or synchrony). Archaeology tries to dissect these sites by applying diverse methods, technical means and interdisciplinary lines of research. For the most part, karst deposits with long archaeological occupations have been found to be low-resolution palimpsests that hinder the identification of human activities and occupational patterns [1-4].

Lateral Gallery 1 (GL1) in Cova del Gegant has been described in several publications, mostly concerning the chronological framework $[5,6]$ and human remains. The first descriptions of two Neanderthal specimens from GL1 (namely Gegant-1 and Gegant-2) [7-10] led to renewed interest in the site. A chronostratigraphic approach was proposed with the goal of placing both remains in sequence $[5,11]$. Faunal remains were also analysed to explore the role of carnivores in the accumulation $[10,12,13]$. The first results concerning 
GL1 were published subsequently [12,13], and showed that the cave was mainly used as a carnivore den; there were carnivore remains, coprolites and evidence of damage inflicted to ungulate bones, mainly by hyenas.

Neanderthals inhabited an extensive geographical area with a wide range of environmental conditions, extending from the westernmost part of Europe to Central Asia between Middle and Upper Pleistocene, 350-37.5 ka. They are known to be descendants of Middle Pleistocene regional populations $[14,15]$. The fate of the Neanderthal groups remains an important focus of research into human evolution, and much of this debate centres on south-western Europe [16]. After decades of investigation, many topics in Neanderthal research remain unclear, including, among others, the influence of palaeoenvironmental variability on the economy [17], the ways of life of the hunter-gatherer groups, their technology, and their symbolic behaviour.

To further examine the role of agents in the accumulation and to refine the Neanderthal record of the cave, this study aims to reconstruct the context in which the Neanderthal remains (Gegant-1 and Gegant-2) were found. Cova del Gegant is one of the palaeolithic sites in the NE of the Iberian Peninsula that has yielded Neanderthal specimens in association with Middle Palaeolithic artifacts and Pleistocene faunal remains [7,8,18]. Some of the recovered artifacts have been presented previously [5] in a study that provided a preliminary assessment of the Neanderthal context from GL1. This paper expands on that previous study, providing (i) a more detailed description of the chronostratigraphic sequence of GL1, (ii) an improved context for the Neanderthal remains Gegant-1 and Gegant-2, and (iii) a contextualisation of human occupancies inside the Middle Palaeolithic record. To achieve these goals, we present a synoptic overview of the chronostratigraphy and data on the large mammal, small vertebrate, bird, lithic and human remains for GL1. The multi-proxy analysis conducted reveals a dynamic of increasing occupation during the Upper Pleistocene in the Iberian Peninsula.

\section{Study Area and Site Description}

Cova del Gegant is located in the Garraf Massif, a horst composed mainly of Mesozoic rocks [19]. The massif is a low-relief mountain range that rises to a height of almost $600 \mathrm{~m}$, and the central part is dominated by karst landform [20]. The morphological elements that make up this sector are defined by the structural history, lithology, and sea level fluctuations. The cliffy coast is mainly composed of calcareous Mesozoic outcrops, and sandy beaches are created by the longshore dynamics [21]. The most important landform in the area is the Riera de Ribes delta where the present-day shore is eroded by transgression. The detailed regional context, including geology and bathymetry, is shown in Figure 1. The area is located in the meso- and thermo-Mediterranean zone, which is composed primarily of evergreen oak forest (Quercion ilicis) with a few deciduous oak communities. The presence of carbonate outcrops has favoured the development of thermo-Mediterranean vegetation (Oleo-Ceratonion) characterised by the presence of Quercus coccifera, Olea europaea, Pistacia lentiscus, Pinus halepensis and Chamaerops humilis [22].

Cova del Gegant (Punta de les Coves, Sitges, Barcelona) is a complex karstic system located in the south-west edge of the massif in front of the Mediterranean sea $\left(1^{\circ} 46^{\prime} 27.33^{\prime \prime} \mathrm{E}\right.$, $41^{\circ} 13^{\prime} 24.75^{\prime \prime} \mathrm{N}$ ) (Figure 2(1,2)). A small joint system in the limestone rock, sea level fluctuations and water table oscillations favoured the development of several caves in the area, which include the adjacent Cova Llarga or de la Trompeta (connected by a narrow passage, GL-T), Cova del Musclo, Cova de la Masia de les Coves, Cova Verda and Cova de l'Aina. The caves are accessible via a horizontal entrance located at sea level and partially eroded by sea waves (Figure 2(4)). Cova del Gegant has several galleries (Figure 2(5)) located a few metres above sea level, where archaeological sediments have been preserved. Cova del Gegant is mainly formed by three different chambers, one large gallery that is $22 \mathrm{~m}$ long (GP1 + GP2) and two lateral galleries (GL) that are almost parallel to each other; one closer to the sea (GL1) (Figure 2(6)) and the other deeper inside the cave (GL2) (Figure 2(5)). Two small remnants of cemented sediments are preserved from sea erosion, 
one between Cova del Gegant and Cova Llarga and the other close to the GL1 entrance (BPII). The former yielded a Levallois point (Figure 2(3)).

Previous excavations at Cova del Gegant were mainly carried out in Lateral Gallery 1 (GL1). The site was probably discovered in 1880 during the construction of a rail trench [23], photographed at the beginning of the twentieth century and first excavated in 1952 by the Agrupació Muntanyenca de Sitges (AMUNT), under the supervision of the palaeontologist Santiago Casanova [24]. Following this, excavations took place during the 1960s and 1970s [25-27], and additional campaigns were undertaken in 1985 and 1989 to save material threatened by coastal erosion [28-31]. The current fieldwork were started in 2007 by the Grup de Recerca del Quaternari at the University of Barcelona. This group has focused on a section of preserved sediments at the back of the main gallery (GP2).

The publication of the Gegant-1 and Gegant-2 specimens [7-9] recovered from a lateral gallery (GL1) has renewed interest in the cave. The chronostratigraphic proposal was constructed using previous stratigraphic data and sediments preserved in the cave with the goal of contextualizing the human remains $[5,11]$. Subsequently, two new Neanderthal remains (namely Gegant- 4 and Gegant-5) were recovered at the rear of the main gallery (GP2) [18]. Faunal remains, a few stone tools and a large number of coprolites from within the archaeological layers point to hominin and carnivore occupation of the site in the past [32].

The stratigraphic sequence at Cova del Gegant was grouped [6-8] into eight site formation episodes from the Late Pleistocene (Episodes 1-3), ca. 145-30 ka, to the Holocene (Episodes 4-7), alternating between periods of continental and marine sediment deposition and periods of coastal erosion. Episode 0 occurs at the base of the sequence and is represented by layer XV (GL1 and GP2), which consists of a thin layer of endokarstic red clay deposit. This is followed by Episode 1, which corresponds to Middle Palaeolithic occupancies and is represented by several layers (XXX, V and probably also layer XVII, $\mathrm{XVIII}$ and $\mathrm{XVa} / \mathrm{b}$ ). Above this deposit, Episodes 2 and 3 contain the Upper Palaeolithic record, the former represented by layers IV, (GP2), XIIb (GL2) and VIII (GP1) and the latter composed of layers III, II and IIb (GP, GL2), and part of layer IX (GP1). The chronological framework of the episodes is mainly constructed by the existing profile preserved at the rear of the GP2, the Middle Palaeolithic sequence covering 94-52 ka (layer V 94-59 ka and XVII/III ca. 60-52 ka), a Châtelperronian/Aurignacian section spanning 43-39 ka (layer IV), and a Late Aurignacian/Gravettian section spanning 34-32 ka (layer III-II).

Episode 4 (Late Bell Beaker) is the oldest of the Holocene layers and is represented by layer VI and Ic ${ }_{2}$ (GP and GL2) and layer XXV (GP2). Two additional storage pits (Silo 1 and Silo 2) are probably related to the same episode formation. Episode 5, represented by layers VII, X and XI in the GP1 sector and $\mathrm{Ib}_{2 \mathrm{dsup}}$ and $\mathrm{Ib}_{\mathrm{d} 2 \text { base }}$ (in GP2), corresponds to an erosive transgression that emptied part of the deposit and accumulated beach sand between the Iron Age and the Middle Ages. Episode 6 is the most recent depositional event and is characterised by layers $\mathrm{Ia}_{1} \mathrm{Ia}_{3}, \mathrm{Ib}_{2 \mathrm{~b}}, \mathrm{Ib} 2 \mathrm{c}$, Ic, Ie, and If (Middle Ages to Early Modern Period). Episode 7 corresponds to current sea erosion [5]. 

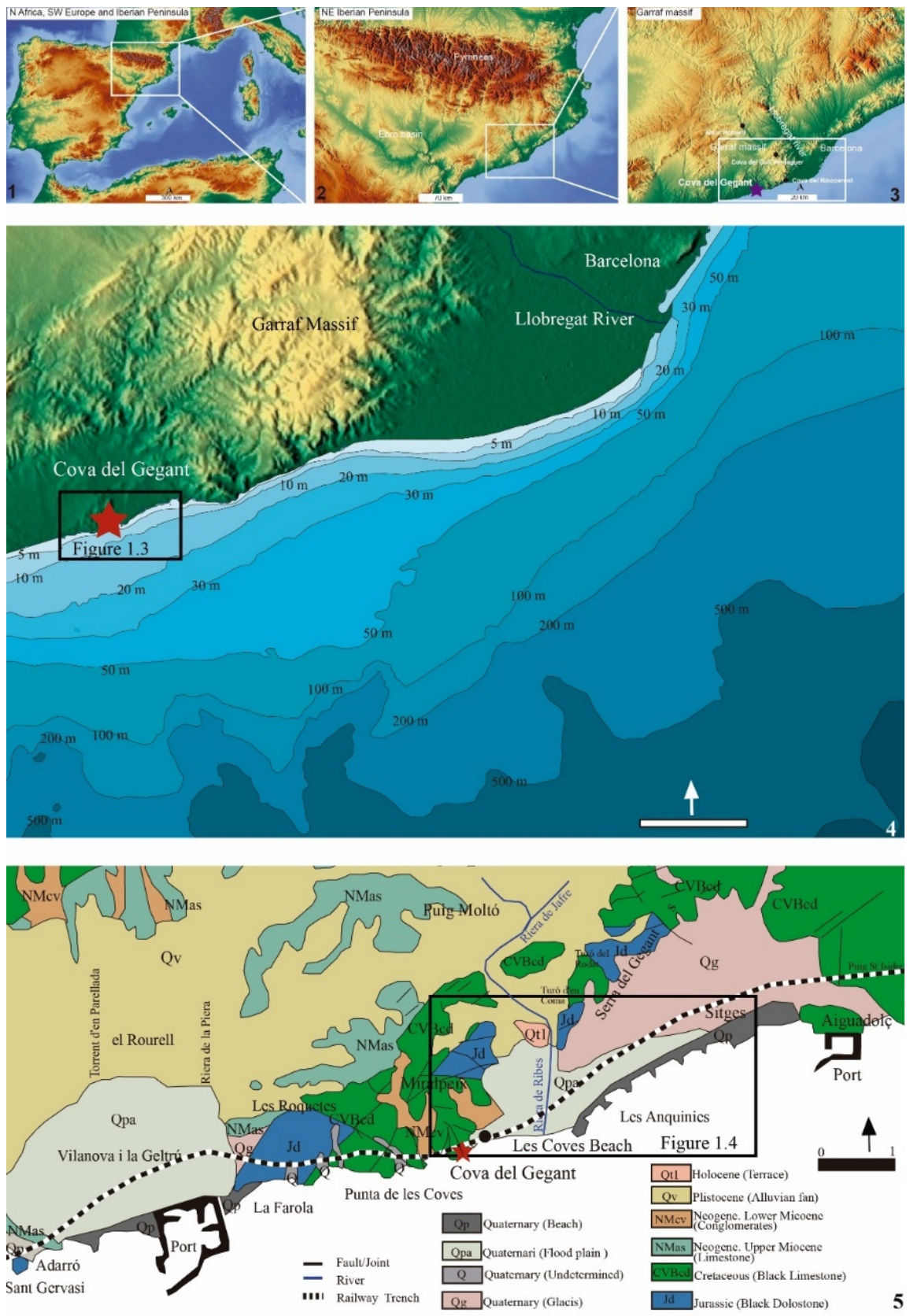

Figure 1. Regional context of Cova del Gegant. (1-3): Location of the archaeological site. The map was downloaded from http://maps-for-free.com/ (@ OpenStreetMap contributors, accessed on 21 December 2021). The cartography in the OpenStreetMap map tiles is licensed under CC BY-SA (www.openstreetmap.org/copyright, accessed on 21 December 2021). The licence terms can be found on the following link: http:/ / creativecommons.org/licenses/by-sa/2.0/ (accessed on 21 December 2021). (4): Topography and bathymetry of the Barcelona area, showing major isobaths. (5): Regional geology based on ICGC data base. 

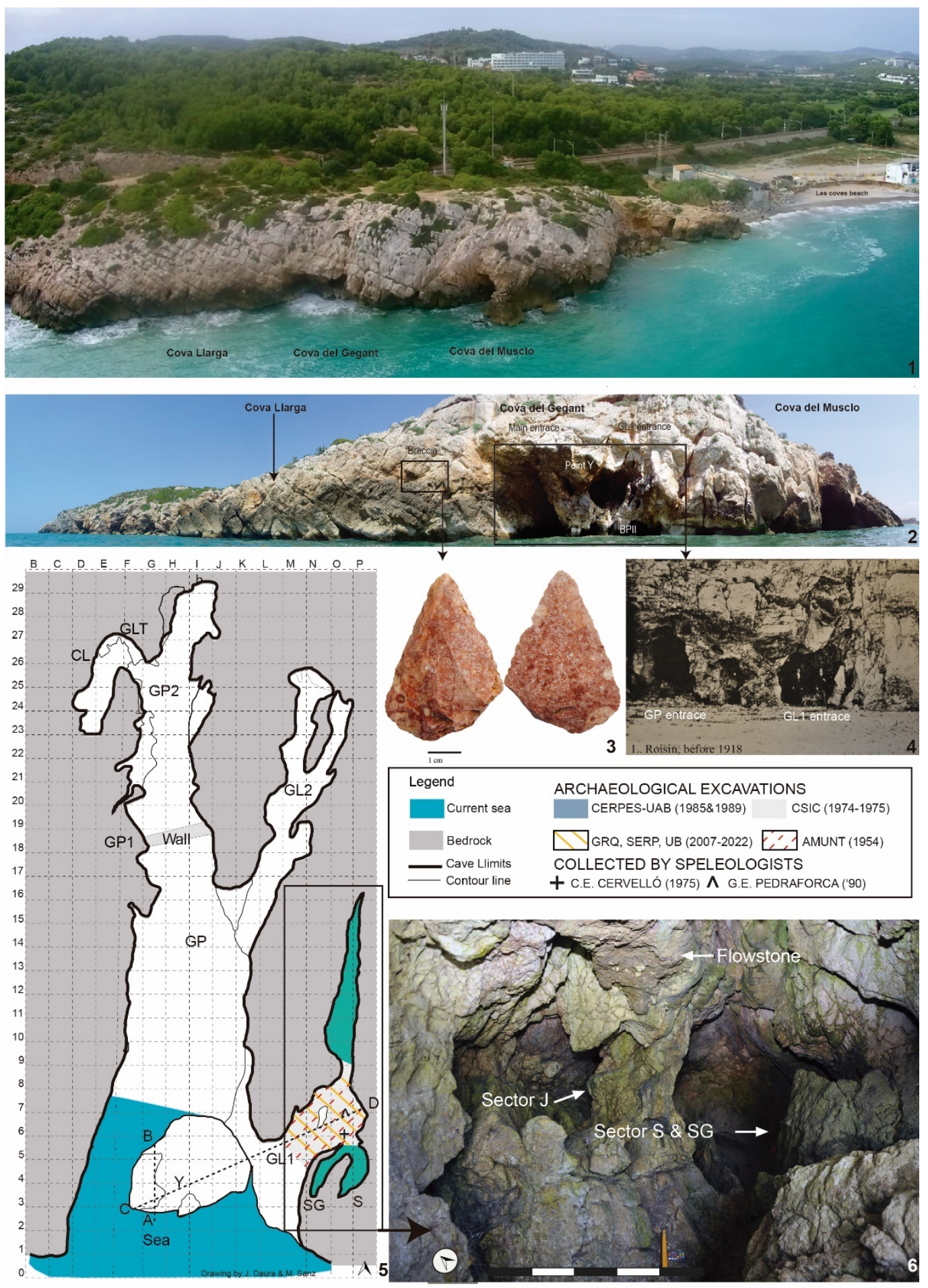

Figure 2. Cova del Gegant. (1): Drone view in 2017. (2): Panoramic view in 2012. (3): Levallois point recovered from the external breccia. (4): Cova del Gegant and Cova del Musclo before 1918 (L. Roisin, Arxiu Històric de Sitges, J. Mates Collection). (5): Plan of the site indicating fieldwork carried out in GL1. (6): Detailed view of GL1 in 2005.

\section{Materials and Methods}

The present study includes the revision of archaeological materials recovered during several field seasons conducted between 1956 and 2022. Table 1 summarises the archaeological excavations in GL1 and the museums where the materials are stored. The materials analysed here include small vertebrates, large mammals, birds, lithic artifacts and human 
remains. All of the archaeological and palaeontological collections from previous campaigns have been analysed with the exception of the materials from 1985 and 1989 because permission has not been obtained. However, the accounts have been included and are summarised here according to the published data.

\subsection{Dating Methods}

Two different dating methods were applied in the GL1 gallery to construct the chronological framework: U-Th dating of speleothems and bones, and luminescence dating of sediments. A detailed methodological description for each technique and the sample provenience has been explained in detail in Daura et al. [5,6]. In summary U-Th dating of the flowstone sealing the GL1 (sample \#2) was performed using alpha-spectrometers BR-024-450-100 ORTEC OCTETE PLUS at the Institute of Earth Sciences Jaume Almera (ICTA-CSIC) [5]. The chemical separation and purification followed the procedure described by Bischoff et al. [33] and the age was calculated using the UDATE program devised by Rosenbauer [34]. The same speleothem was re-sampled (samples \#5 and \#6) using updated methods, and isotopes were measured on a ThermoFinnigan Neptune MC-ICPMS with a Cetac Aridus II and a Savillex PFA $50 \mu \mathrm{L} / \mathrm{min}$ microconcentric nebuliser. The pre-treatment processes used for the U-Th samples are described in Hoffmann et al. [35], while the measurement methods and protocols follow Hoffmann [36] and Hoffmann et al. [37,38]. The Neanderthal mandible (Gegant-1) (samples \#3 and \#4) was directly dated using the Difusion-Adsorption (D-A) model [39] to account for uranium uptake. U-Th isotopes were measured by the laser ablation multi collector ICP-MS hosted at the University of Bristol using the methodology described by Pike et al. [40].

The luminescence dating (IRSL) of polymineral fine grains (sample \#1) was carried out at the Laboratorio de Datación y Radioquímica, Universidad Autónoma de Madrid following Valero-Garcés et al. [41]. The chemical and physical treatment followed procedures described by Aitken [42], and the conversion factors of Nambi and Aitken [43] were used to derive alpha, beta and gamma dose rate estimates from measured elemental concentrations and specific activities. Measurements were carried out on a Risø TL-DA-10 reader equipped with IR LEDs and a calibrated 90Sr/90Y beta source.

\subsection{Faunal Remains}

The faunal remains described here include all of the collections from GL1 that are housed at the institutions listed in Table 1 [13]. The collection of the Universitat Autonoma de Barcelona (UAB) was not available for this study, and for this reason the data from this collection included here are from a previous archaeological report [29]. The information on the rhinoceros is from previous studies [44] and the quantification was updated using available data [45].

The analysis of large mammal bones (not including leporids) involved the classification of the skeletal specimens identifiable at genus or species level following conventional zooarchaeological criteria [3,46]. The unidentifiable bones were catalogued to bone tissue types (i.e., long, flat, or spongy bones). The number of remains (NR), the minimum number of individuals (MNI) and the number of identified specimens (NISP) were estimated and calculated for a given taxon/genus [47-49]. Five age categories, such as foetal/neonatal, infant, juvenile, adult and senile, are used in the classification of age groups.

Bones were analysed following standard taphonomic methods [50,51]. Bone surfaces were examined under a binocular device (MOTIC SFC-121 GG). Human modifications were identified by butchery damage and breakage [52,53]. Carnivore damage was diagnosed by gnawing modifications and breakage [54,55]. Burning categories were described according to surface colour, fractures, in relation to angle, outline and edge and weathering based on the criteria proposed by Behrensmeyer [56]. 
Table 1. Information summarising excavations conducted at GL1.

\begin{tabular}{|c|c|c|c|c|}
\hline Year & Direction & Institution & Materials Stored & Acronyms \\
\hline 1954 & S. Casanova & AMUNT & $\begin{array}{l}\text { Arxiu Històric Municipal de Sites, } \\
\text { Museu Mar i Cel, Museu Arqueològic } \\
\text { de Catalunya }\end{array}$ & $\begin{array}{l}\text { AHSI } \\
\text { MMC } \\
\text { MAC }\end{array}$ \\
\hline $1972,1974-75$ & R. Viñas-J. Villalta & Secció Ecologia Quaternari- Institut Jaume Almera & $\begin{array}{l}\text { Museu Geològic de Barcelona } \\
\text { Museu Arqueològic de Catalunya }\end{array}$ & $\begin{array}{l}\text { MGB } \\
\text { MAC }\end{array}$ \\
\hline 70 & Collected by speleologists (A. Asensio) & Centre Espeleològic Cervelló & Universitat de Barcelona & UB-1 \\
\hline 1985 & J. Martínez- R. Mora- I. Muro- J. Miret & $\begin{array}{c}\text { Centre de Recerques Palaeoecosocials de Girona i de } \\
\text { la Universitat Autònoma de Barcelona }\end{array}$ & Universitat Autònoma de Barcelona & UAB \\
\hline 1989 & J. Martínez- R. Mora- J. Parcerisas- G. Roca & $\begin{array}{l}\text { Centre de Recerques Palaeoecosocials de Girona i de } \\
\text { la Universitat Autònoma de Barcelona }\end{array}$ & Universitat Autònoma de Barcelona & UAB \\
\hline ‘90 & Collected by speleologists (M. Nebot) & Grup Espeleològic Pedraforca & Institut Català de Paleontologia & ICP \\
\hline $2007-2022$ & J. Daura-M. Sanz & $\begin{array}{c}\text { Grup Recerca del Quaternari-SERP (Universitat } \\
\text { Barcelona) }\end{array}$ & Universitat de Barcelona & UB-2 \\
\hline
\end{tabular}


Avian remains and the small vertebrates studied here come from the excavations undertaken by Viñas and Villalta in 1974-1975. Sediments were water screened using $2 \mathrm{~mm}$ and $5 \mathrm{~mm}$ meshes. These remains were hosted at the Museu de Geologia de Barcelona and small vertebrates were previously listed in two catalogues of this museum's collections [57,58] and then analysed [59]. Birds were loaned for a comprehensive study of the birds of the Iberian Quaternary [60].

\subsection{Lithic Assemblage}

The lithic assemblage from Cova del Gegant is the result of various field seasons carried out at the cave. Most artifacts were found during the 1974-1975 ( $\mathrm{n}=30)$ and 1985 ( $n=40$ ) excavations. The main part of this collection was located in gallery GL1, although some lithics were also found in the principal chamber (GP) and gallery GL2. According to Mir [61], the 1974-1975 assemblage was made up of four sidescrapers, three denticulates, three splintered pieces, eighteen flakes and two cores. Besides the high number of retouched implements, this industry was characterised by the presence of Levallois flakes, and a resemblance to the Charentian Mousterian of Ferrassie type was suggested. The 1985 excavation yielded seven sidescrapers, eight denticulates, one point, one endscraper, twenty flakes, one core and two fragments [28]. Additional information on the 1985 materials can be found in other unpublished documents [31,62]. At first sight, the 1974-1975 and 1985 collections appeared similar due to the high proportion of retouched artifacts, the balance between sidescrapers and denticulates, and the predominant use of flint as the raw material. Only four quartz artifacts were found in the 1985 excavation. Some more were recovered in the 1989 excavation, in GL1 and GL2, but they remain unpublished [29]. Finally, four additional artifacts were found in the 2007 field season: three in GL1 and one in GP.

Here, we have analysed 33 artifacts, including the collection from the 1974-1975 excavation housed at the Museu d'Arqueologia de Catalunya (Barcelona), and three artifacts from GL1 found in the 2007-2022 excavation. Although this is only a part of the Cova del Gegant lithic assemblage, it allows us to make some qualitative assessments of their technological features.

The method used in the study applied an attribute analysis. The attributes related to dimensions (length, width, and thickness) were recorded for all the artifact classes (cores, flakes and retouched tools). Lithics were classified according to five size categories established by multiplying length by width: very small $<500 \mathrm{~mm}^{2}$, small $500-1000 \mathrm{~mm}^{2}$, medium 1000-1500 $\mathrm{mm}^{2}$, large $1500-2000 \mathrm{~mm}^{2}$ and very large $>2000 \mathrm{~mm}^{2}$.

The attributes recorded for the cores were related to their structure, including the number and characteristics of striking platforms and flaking surfaces. We also considered the hierarchisation of the flaking surfaces and reduction degree. The attributes recorded for flakes were the following: presence of cortex in the striking platform (cortical or uncortical), striking platform type (flat, linear or punctiform), striking platform faceting (unprepared, dihedral, multifaceted), amount of cortex in the dorsal face, bulb of percussion type (marked or diffuse), and curvature of the ventral face (concave, convex, straight or winding). For the retouched artifacts, we used the attribute analysis and the typological system of Laplace [63].

\subsection{Human Remains}

Two Neanderthal remains were identified in GL1. The mandible Gegant-1 was recovered during the 1952 excavation conducted by Santiago Casanova and was not recognised until 2001 [7]. The mandible was stored between 1998 and 2008 at the Arxiu Historic de Sitges and is now exhibited at the Museu d'Arqueologia de Catalunya.

A Neanderthal tooth (incisor) was recovered during the 1974 and 1975 excavations and stored at the Museu de Geologia de Barcelona as part of the Villalta collection [64,65]. It was kept with other dental remains and was not identified as Neanderthal until the study of the palaeontological collection of faunal remains [10], and was subsequently published [8]. 
The tooth was labelled twice. One label refers to the museum reference (V-2828) and the second to the excavation record showing grid provenance (c-5) and depth (0-30 cm below the 1975 datum).

\section{Results}

\subsection{GL1 Stratigraphy and Chronology}

GL1 is the closest gallery to the sea and today is exposed to sea erosion. Remnant sediments are still visible, adhering in the breccia at point $Y$ and to the rear of GL1. Figure 2(5) shows the location of the profiles described here and Figure $3(3,4,6)$ shows the sedimentary architecture of this cave section as preserved in 2007. Profile C-D is a 10-m-long section, which allows us to correlate the layers where the Cova del Gegant's human mandible (Gegant-1) and incisor (Gegant-2) were found with the rest of the cavity. Figure 3(1,2) correlates the previous stratigraphic sequences of the 1954 campaign, Masriera's sedimentological study [66], Viñas and Villalta [25] and the 1985 excavation [62] with the current stratigraphic log. A stalagmitic flowstone (Figure 3(2,5)) located at the top of the sequence seals part of the sediment fill and has been dated by means of alpha-spectrometry and TIMS methodology (samples \#2 and \#5/6 respectively). Two different, distinct units have been identified in the preserved sediments. These units are related to episodes described in Daura et al. [5]. Episode 1 is preserved at the top of the gallery entrance (breccia at point $Y$ ) (Figure 3(3,4)) and at the rear of GL1 (Figure 3(5)). In GL1, this episode is represented by layer $\mathrm{XVa}$, preserved under the stalagmitic flower and at the vertex of the triangle formed by the gallery morphology $(\mathrm{XVb})$. It is a hard-cemented breccia composed of angular pebbles and pink (Munsell 7.5YR 7/4) lutitic matrix. At the breccia at point Y, concretion has helped preservation from maritime activity and the identified layers present similarities with $\mathrm{XVa} / \mathrm{b}$. However, this correlation is tentative because there is a large horizontal discontinuity between the two remnants. Layers XVII $(a / b)$ and XVIII present boulder and angular pebbles in a brown lutitic matrix. Bones and coprolites are visible. Between the cave entrance and the sea, another remnant of cemented breccia (BPII) is stuck to the bedrock, is very strongly cemented and is difficult to study. Its existence indicates that most of Cova del Gegant's external part was filled with sediment, which is no longer present (Figure 3(3)). Episode 0 is only located at the gallery base and is represented by layer XVI. It consists of red endokarstic clay with no archaeological remains.

The speleothem located at the top of GL1 and capping layer XVa has been dated twice. On the first occasion, the alpha spectrometry (Table 2, sample \#2) method was used to provide an approach to the age range. The nominal age obtained of $49.4 \pm 1.8 \mathrm{ka}$ may be slightly too high as a consequence of 232 Th contamination. MC-ICPMS (Table 2, sample \#5 and 6) were used to re-sample this speleothem and 232Th was used as a proxy for detrital contribution, which in general is not high. The uncorrected nominal age for the basal speleothem layer shows similarities with the alpha methodology results. However, after correction, it gives an age of $47.1 \pm 1.2 \mathrm{ka}$ ( $2 \sigma$ uncertainty) for the basal layer and $45.5 \pm 0.4 \mathrm{ka}$ for the uppermost layer. Assuming that the Neanderthal mandible was located at the top of layer XVa and that the uranium adsorption was rapid, its direct dating result of $52.3 \pm 2.3 \mathrm{ka}$ ( $2 \sigma$ uncertainty) (Table 2, samples \#5 and \#6) is consistent with the capping flowstone. The IRSL date for the medial and basal deposit $(\mathrm{XVb})$ from the gallery at $60.1 \pm 3.9 \mathrm{ka}(1 \sigma)$ provides the maximum age for the entire deposit preserved at GL1 (Table 2, sample \#1). Figure 3(2) summarises and correlates the previous excavation and the layer identified in a single log related to the current site episodes (Figure 3(1)). 
Table 2. Final ages of the GL1 gallery from the Cova del Gegant site. Luminescence mean \pm total uncertainty $(1 \sigma$ or $68 \%$ confidence interval), calculated as the quadratic sum of the random and systematic uncertainties. U-series dating results for speleothems from Cova del Gegant (2 $\sigma$ confidence interval). All ratios are activity ratios calculated from isotope concentration ratios using decay constants according to Jaffey et al. [67] ( $\lambda 238)$, Cheng et al. [68] ( $\lambda 234$ and $\lambda 230)$ and Holden [69] ( $\lambda 232)$.

\begin{tabular}{|c|c|c|c|c|c|c|c|c|}
\hline \multicolumn{9}{|c|}{ Luminescence (IRSL) } \\
\hline$\#$ & Sample Name & Layer & Mineral & Grain Size $(\mu \mathrm{m})$ & $\begin{array}{c}\text { Total Dose Rate } \\
\text { (Gy/ka) }\end{array}$ & $\begin{array}{c}D_{e} \\
(G y)\end{array}$ & & $\begin{array}{c}\text { Age } \\
\text { ka (1б) }\end{array}$ \\
\hline 1 & MAD-5642 & $\mathrm{XVb}$ & Polymineral & $2-10$ & $1.59 \pm 0.10$ & $95.5 \pm 2.2$ & & $60.1 \pm 3.9$ \\
\hline \multicolumn{9}{|c|}{ U-series } \\
\hline & Lab \# & Layer & ${ }^{238} \mathbf{U}$ & ${ }^{232} \mathrm{Th}$ & ${ }^{234} U /{ }^{238} U$ & ${ }^{230} \mathrm{Th} /{ }^{238} \mathrm{U}$ & ${ }^{230} \mathrm{Th} /{ }^{232} \mathrm{Th}$ & Age ka $(2 \sigma)$ \\
\hline 2 & 6006 & $\mathrm{XVa}$ & 0.22 & 0.03 & $1.16 \pm 0.03$ & - & 10.48 & $49.4 \pm 1.8$ \\
\hline 3 & JD52a & $\mathrm{XVa} / \mathrm{b}$ & $\mathrm{n} / \mathrm{a}$ & $\mathrm{n} / \mathrm{a}$ & $1.262 \pm 0.017$ & $0.495 \pm 0.023$ & $>100$ & $53.2 \pm 3.3$ \\
\hline 5 & UEVA 1028 & XVa & $367.64 \pm 3.58$ & $37.63 \pm 0.39$ & $1.1615 \pm 0.0024$ & $0.4281 \pm 0.0023$ & $12.78 \pm 0.06$ & $47.11 \pm 1.21$ \\
\hline 6 & UEVA 1029 & $\mathrm{XVa}$ & $37.63 \pm 0.70$ & $0.191 \pm 0.004$ & $1.1621 \pm 0.0030$ & $0.3933 \pm 0.0028$ & $237.01 \pm 2.40$ & $44.51 \pm 0.42$ \\
\hline
\end{tabular}




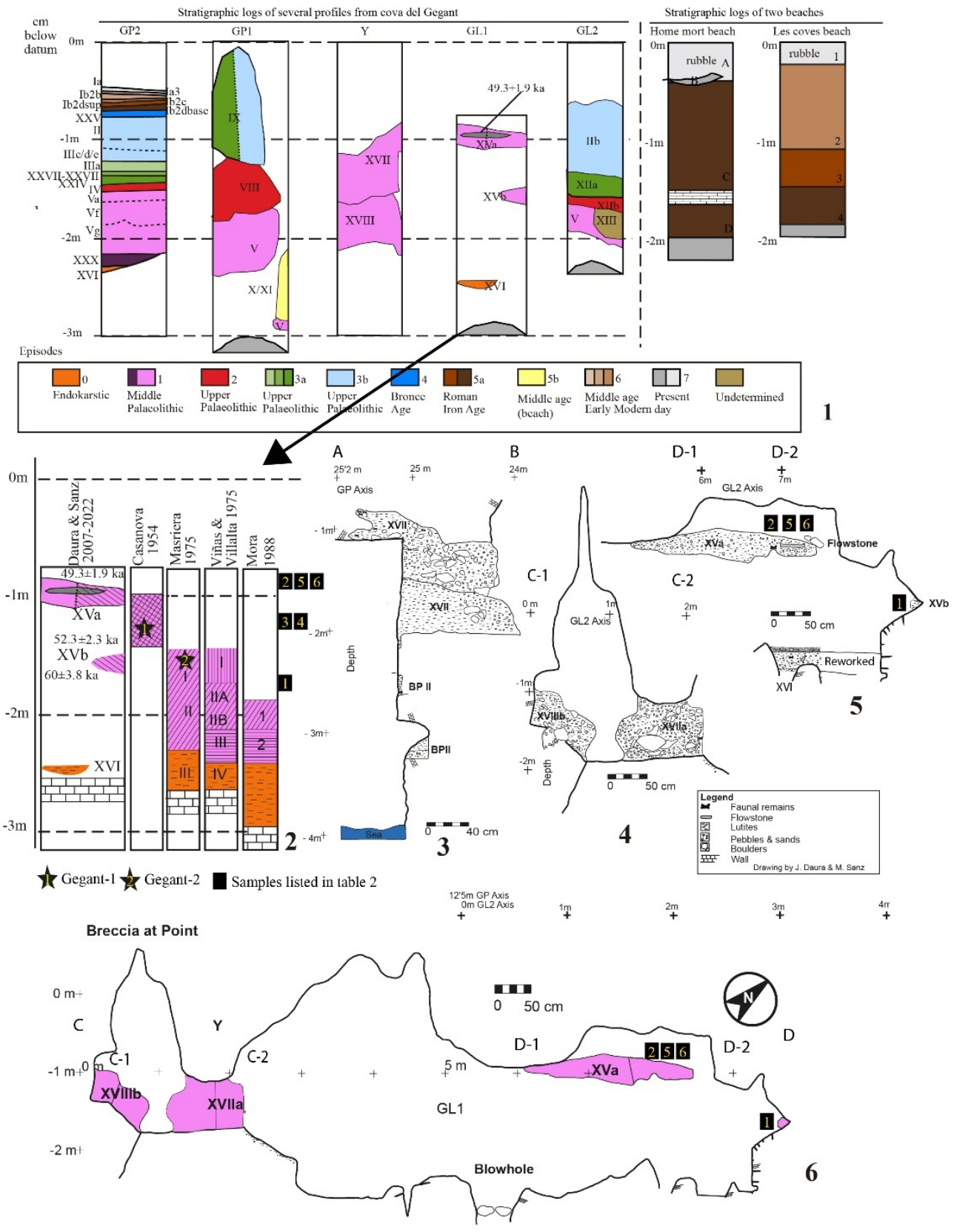

Figure 3. (1): Stratigraphy and correlation of the Cova del Gegant's logs. (2): GL1 logs integrating previous excavations. (3): Transversal profile in the point $Y$ breccia. (4): Transversal profile in the point $Y$ breccia. (5): GL-1 section. (6): GL-1 cross section.

\subsection{Neanderthal Remains}

Two Neanderthal remains have been recovered at GL1 (Figure 4). The mandible Gegant-1 (Figure 4(1) and Supplementary Materials) is represented by three fragments that comprise part of the mandibular corpus from the right M1 tooth socket to the mesial margin of the left M3 alveolus. No teeth are preserved along the specimen, but the distal root of the left M2 is present in its root socket. The alveolar margin of the specimen is abraded. The absence of teeth make it hard to determine the age at death, but the presence and development of the preserved root and root sockets indicate a minimum age at death of around 15 years. The mandible presents clear archaic features which correspond to Neanderthals: (i) the lack of a bony chin, (ii) the posterior placement of the anatomical structures and (iii) the low position of the mental foramen. 
Gegant-2 (Figure 4(2)) is a lower left lateral permanent incisor (I2) which preserves the entire crown but approximately a third of the apical root is missing. The size of the anterior teeth helps to assess the taxonomic affinities of the Cova del Gegant tooth. The buccolingual and mesiodistal dimensions and discriminant analysis of these two variables characterise it as a Neanderthal specimen. The root tip was broken postmortem, making it difficult to determine the time of death. The degree of tooth wear suggests that the tooth belonged to a second individual from the site, who was perhaps around 10 years old.

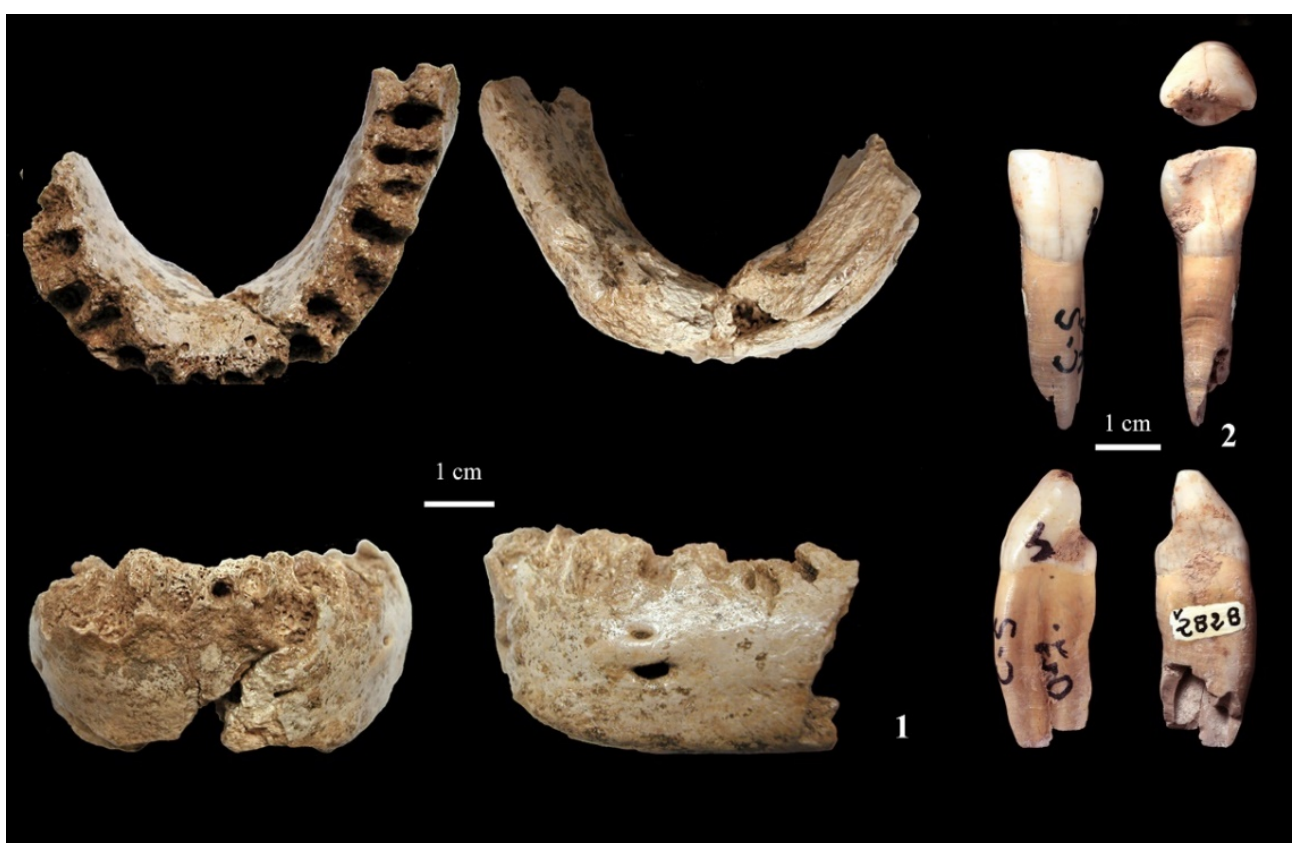

Figure 4. Neanderthal remains identified at GL1 from Cova del Gegant. (1): Different views of the adult mandible Gegant-1. (2): The lower incisor, Gegant-2, from an individual of 10 years old.

\subsection{Large Mammals}

Table 3 shows the results of the identification of large mammals in GL1. Equids are the most abundant taxa $(34 \%$ NISP, NISP $=894)$, followed by red deer $(17 \%$ NISP, NISP $=448)$ and large bovids $(7 \%$ NISP, NISP $=186)$. Carnivores are also represented in the assemblage. The most abundant is the hyena $(7 \%$ NISP, NISP $=179)$. Other taxa are less frequent, and include rhinoceros ( $1 \%$ NISP, NISP $=36)$, ibex $(\leq 1 \%$ NISP, NISP $=18)$, proboscideans $(\leq 1 \%$ NISP, NISP $=7)$ and wild boar $(\leq 1 \%$ NISP, NISP $=10)$. Other less frequent carnivores are the wild cat $(1 \%$ NISP, NISP $=40)$, Iberian lynx $(1 \%$ NISP, NISP $=30)$, leopard $(\leq 1 \%$ del NISP, NISP = 13), wolf $(1 \%$ NISP, NISP $=28)$, brown bear $(\leq 1 \%$ NISP, NISP $=19)$, fox $(\leq 1 \%$ NISP, NISP $=11)$, dhole $(\leq 1 \%$ del NISP, NISP $=6)$ and badger $(\leq 1 \%$ del NISP, NISP = 3). Following Discamps [70] and based on MNI values, we estimated the ungulate biomass index for the GL1 assemblage, which equals 0.7 . This value is closer to the index for modern-day grasslands (index $=1$ ), with a biomass higher than 3 ton $/ \mathrm{km}^{2}$, than to the value for forest and tundra biomes (index $=0$ ), with a biomass lower than $1 \mathrm{ton} / \mathrm{km}^{2}$. This implies the presence of vegetation that can support and feed large herbivores and indicates an open landscape environment rather than forested areas close to the study site.

Adult individuals (ungulates and carnivores) are the most abundant (56\%) in the assemblage (Figure 5). Hyena individuals are represented by several ontogenetic ages. Infants and juveniles are most abundant among the carnivores. Equids are dominated by adults and the same can be said for deer and large bovids. A single foetal remain has been identified, probably from a perissodactyl. 
Table 3. Number of Identified Specimens (NISP) and Minimum Number of Individuals (MNI) of the large mammals identified at GL1.

\begin{tabular}{lcc}
\hline & NISP & MNI \\
\hline Carnivora & 329 & 55 \\
Canis lupus & 28 & 5 \\
Vulpes vulpes & 11 & 1 \\
Ursus sp./U. arctos & 19 & 2 \\
Meles meles & 3 & 1 \\
Crocuta crocuta & 179 & 24 \\
Felis silvestris & 40 & 8 \\
Lynx pardinus & 30 & 7 \\
Panthera pardus & 13 & 5 \\
Cuon alpinus & 6 & 2 \\
Artiodactyla & 662 & 47 \\
Sus scrofa & 10 & 3 \\
Cervus elaphus & 448 & 22 \\
Bos/Bison & 103 & 19 \\
Bison priscus & 18 & \\
Bos primigenius & 65 & 3 \\
Capra pyrenaica & 18 & 49 \\
Perissodactyla & 930 & 40 \\
Equus ferus & 823 & 7 \\
Equus hydruntinus & 71 & 2 \\
Stephanorhinus hemitoechus & 36 & 1 \\
Proboscidea & 7 & \\
Elephas sp. & 3 & 1 \\
Proboscidea indet. & 4 & \\
Undetermined & & \\
Macrofauna indet. & 674 & 152 \\
Total & 2602 & \\
\hline
\end{tabular}

The skeletal frequencies are similar for ungulates and carnivores. The cranial elements are the most abundant ( $\mathrm{NR}=592$ for ungulates and $\mathrm{NR}=161$ for carnivores), and isolated dentition is the most represented. Autopodium elements are also relevant ( $\mathrm{NR}=305$ for ungulates and NR $=55$ for carnivores). The other skeletal elements are less frequent.

The main taphonomic processes that had affected the bones were concretion $(34 \%)$ and manganese coatings (23\%), but they show only a low degree of alteration. Abrasion is observed in $15 \%$ of the remains and presents different degrees of alteration, in some cases affecting only a small area and in others a large part of the surface. Exfoliation (5\%) and desquamation $(7 \%)$ are also present. Less frequent are rodent activity $(2 \%)$, trampling $(2 \%)$, root etching, sediment pressure and dissolution $(\leq 1 \%)$.

The abundant biological activity observed in bones is due to carnivore ravaging. Furrows are frequent $(3 \%)$, epiphyses may have been gnawed away and hollowed out $(2 \%)$, and pitting is present $(1 \%)$. Digested bones are scarce $(\leq 1 \%)$. No direct anthropogenic activity on the bones is documented (e.g., cut-marks, diagnostic elements of bone breakage, etc.), and burned bones are scarce $(\leq 1 \%)$ (Figure 6$)$.

Two fracture morphologies are observed: the first by oblique angles (34\%) with a curved outline (59\%) and a smooth surface (39\%), which suggests fresh-bone breakage, and the second with right $(28 \%)$ and mixed angles $(38 \%)$, transversal $(34 \%)$ and an irregular fracture surface $(61 \%)$, which suggests dry-bone breakage. 


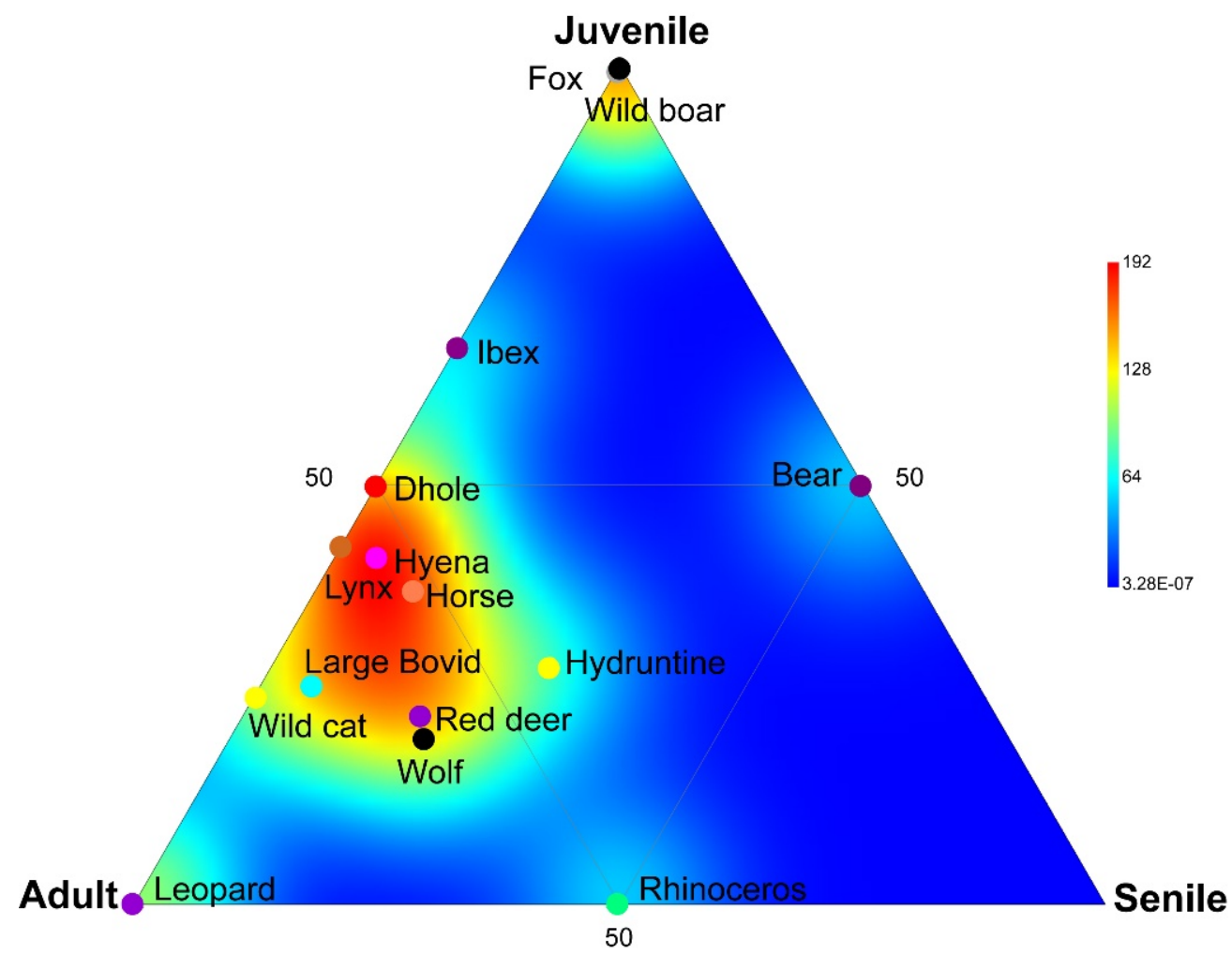

Figure 5. Ternary plot distribution of large mammals from Cova del Gegant-GL1. Dots indicate the percentage median of individuals for juveniles, adults, and senile individuals. Analysis was performed using PAST software [71].

Equid and large bovid metapodials are almost complete, and damage inflicted by carnivores is restricted to distal condyles. The consumption of stylopodium epiphyses reduced them to bone cylinders. Medium-sized and small ungulates are totally different, with a predominance of broken shafts.

Complete specimens are scarce in the assemblage $(\leq 7 \%)$. Specimens with some preserved epiphyses mainly have a shaft length of less than a half (70\%). A total of $95 \%$ of the shafts analysed preserve less than half of their original circumference and $97 \%$ less than half of the bone length, while complete sections and lengths are very few in number.

\subsection{Birds}

The skeletal avian elements recovered in GL1 are grouped into four distribution layers by Viñas and Villalta (1975) and compose quite a wide, varied taxonomic assemblage (Table 4). These remains have been studied previously by Sánchez-Marco [60,72]. Findings under the heading "unknown layer of provenance" (the rightmost column in Table 4) have not been considered in the present study as they appeared to be mixed with fossils from more modern periods [60]. The approximately 25 recognised species indicate a complex landscape, made up of diverse habitats. The avian remains attributed to the red-legged partridge (Alectoris rufa) are among the earliest evidence of this species. The earliest dates recorded for this species at eastern and southern Iberian sites are around 50 to $40 \mathrm{ka}$, which can be understood as evidence of its appearance around that time in the lberian Mediterranean region [73].

Species that today exhibit a resident phenological pattern form the majority of the entire avian assemblage, in contrast to the low representation of wintering and breeding species. However, according to current phenological patterns, all species may hold resident status. The occurrence of the Manx shearwater, Puffinus puffinus, is likely explained by its behaviour of digging burrows in soft coastal terrains. Anthus spinoletta is a montane passeriform, linked to bodies of water. An environment with open spaces is denoted 
by many taxa, such as all corvids (P. pica, both Pyrrhocorax and both Corvus), Sturnus, E. calandra, C. coturnix, Columba, A. noctua and F. tinnunculus, species that are very common in the Iberian and European Pleistocene [74].

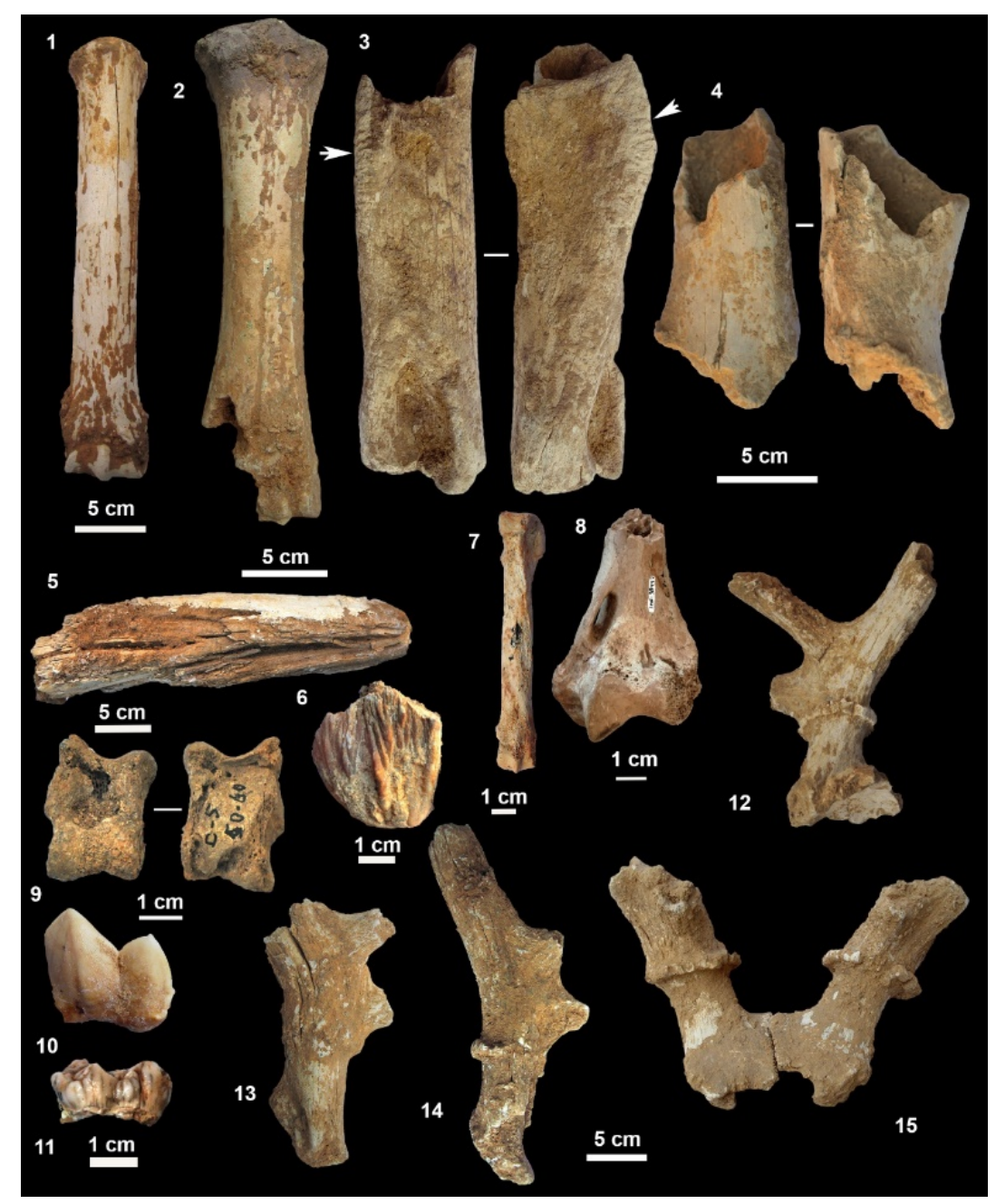

Figure 6. Faunal remains from GL1 stored at Museu de Geologia de Barcelona (MGB) and Arxiu Històric de Sitges (AHSI). (1): Equid metatarsal (AHSI). (2): Large bovid metacarpal (AHSI) showing a distal condyle gnawed away. (3,4): Shaft cylinders of equid humeri showing carnivore damage ((3): AHSI; (4): UB-1). (5): Proboscidean tusk fragment (MGB). (6): Dental fragment of a proboscidean (UB-1). (7): Hyena metacarpal (UB-1). (8): Leopard humerus (ICP). (9): Digested astragalus (MGB). (10): Hyena tooth (AHSI). (11): Wild boar tooth (MGB). (12-15): Red deer frontal bones with antlers ((12): UB-1; (13-15): AHSI).

More unusual in the Iberian avian record is the high representation of species linked to forest habitats documented here. Fringilla coelebs and Carduelis chloris live in woodland edges with thickets. Strix aluco, Loxia pytyopsittacus, Pyrrhula pyrrhula, Coccothraustes coccothraustes and Pinicola enucleator are characteristic inhabitants of more or less open forests $[75,76]$. Among these birds, L. pytyopsittacus and P. enucleator are northern irruptive species. Their presence could be explained by the steady Mediterranean refugia hypothesis, an interpretation of the recording of species with currently northern distributions within associations characterised by Mediterranean species [72]. According to this theory, species, such as Alectoris, have an important role in palaeoclimatic interpretations. These species are typical of the Mediterranean region, have sedentary behaviour and perform short movements throughout the year. Their occurrence is incompatible with cold weather conditions. The occurrence of northern irruptive birds in the warmer areas of the European peninsula 
indicate colder conditions at high continental latitudes, probably due to one of the cold pulses of the late Pleistocene.

The bird assemblage may have been conditioned by taphonomy. It includes species with different behavioural patterns, such as cave-dwelling species, species that used caves sporadically, species that used indoor rocky shelters for night roosting, and others that did not enter caves. Birds linked to rocky habitats may have died in the cavity itself. The large presence of choughs (Pyrrhocorax pyrrhocorax and Pyrrhocorax graculus) in avian assemblages has been commonly attributed to chough nesting and roosting behaviour in rocky cavities. Very recently it has been observed that this pattern of overabundance does not occur with other rock dweller species, and is only observed in caves with evidence of human presence, and as such it has been proposed that these birds may have been hunted since Neanderthal times [77]. Most avian bones recorded correspond to diurnal species, but there are also some nocturnal raptors. All nocturnal birds documented at Cova del Gegant could have been preyed upon by the eagle owl because it eats everything that flies at night; however, this assumption is speculative because there is no evidence of digestion or other signs of predation. Small diurnal birds could have been caught by falcons because they hunt all small birds flying during the day, but this is also speculative. It seems clear that there was no single cause for the accumulation of the birds inside the cave. But regardless of the vectors that introduced the birds into the cave, there is no doubt that the climatic conditions were temperate, as indicated by the presence of partridge (resident status) and quail, and that there were extensive forest masses, totally or partially constituted by conifers, as indicated by a large number of strict indicator species of forest habitats.

\subsection{Small Vertebrates}

A total of 225 small vertebrate remains have been identified, including amphibians, squamate reptiles, insectivores, bats and rodents, corresponding to 96 individuals representing at least 22 species. The small vertebrate (Table 5; Figure 7) association identified in Cova del Gegant is mainly represented by taxa related to Mediterranean forest environments, as in the case of Apodemus sylvaticus, Eliomys quercinus, and Hystrix (A.) cf. brachyura vinogradovi. However, species that prefer open environments are also represented in the association, such as Microtus (Terricola) duodecimcostatus, Microtus arvalis, Erinaceus europaeus, Crocidura russula, and Pelobates cultripes, together with squamates in general. Then, the presence of certain taxa, not currently represented in the Garraf massif, such as Microtus agrestis, Sorex gr. coronatus-araneus and Talpa europaea (Table 6), indicates wetter conditions around the cave than in the present. Nevertheless, the herpetofaunal species Pelobates cultripes and Zamenis scalaris are indicators of drier environments.

To evaluate palaeoclimatic parameters based on the small vertebrate assemblages described in López-García et al. [59], we used the Mutual Ecogeographic Range method [78,79]. This method involves defining the climatic conditions of the area where the fauna of the site currently lives (Table 6). Species like porcupine that do not have extant representatives in the Iberian Peninsula, are not included, but are considered for the interpretation. This method places the small vertebrate assemblage of Cova del Gegant in three $10 \times 10 \mathrm{~km}$ UTM squares of the external Sierras of the Pyrenees in Huesca. These results suggest lower mean annual temperatures $\left(\mathrm{MAT}_{\text {Gegant }}=10 \pm 2.6^{\circ} \mathrm{C}\right.$ ) than at present, where $\mathrm{MAT}_{\text {Current }}=15.3^{\circ} \mathrm{C}$ according to [80] at Barcelona airport meteorological station, nearly $30 \mathrm{~km}$ to the north of the cave. The mean annual precipitations $\left(\mathrm{MAP}_{\mathrm{Gegant}}=850 \pm 150 \mathrm{~mm}\right)$ are higher than present $\left(\mathrm{MAP}_{\text {Current }}=659 \mathrm{~mm}\right)$ and the warmest monthly temperature $\left(\mathrm{MTW}_{\text {Gegant }}=20.1 \pm 1{ }^{\circ} \mathrm{C}\right)$ is lower than today $\left(\mathrm{MTC}_{\text {Current }}=8.8^{\circ} \mathrm{C}\right.$; $\left.\mathrm{MTW}_{\text {Current }}=23.0^{\circ} \mathrm{C}\right)$. 
Table 4. Avian remains documented at GL1.

\begin{tabular}{|c|c|c|c|c|c|c|c|c|c|c|c|c|c|c|c|c|}
\hline \multirow[b]{3}{*}{ Taxa } & \multicolumn{16}{|c|}{ Layers } \\
\hline & \multicolumn{2}{|c|}{ I } & \multicolumn{2}{|c|}{ I-II } & \multicolumn{2}{|c|}{ II } & \multicolumn{2}{|c|}{ III } & \multicolumn{2}{|c|}{ IV } & \multicolumn{2}{|c|}{ Unknown } & \multicolumn{2}{|c|}{ Total NISP } & \multicolumn{2}{|c|}{ Total MNI } \\
\hline & NISP & MNI & NISP & MNI & NISP & MNI & NISP & MNI & NISP & MNI & NISP & MNI & NISP & $\%$ NISP & MNI & $\% \mathrm{MNI}$ \\
\hline Puffinus puffinus & & & & & 1 & 1 & & & & & & & 1 & 0.3 & 1 & 0.7 \\
\hline Falco tinnunculus & 2 & 2 & & & & & & & & & 3 & 1 & 5 & 1.4 & 3 & 2.1 \\
\hline Accipiter nisus & & & & & 1 & 1 & & & & & & & 1 & 0.3 & 1 & 0.7 \\
\hline Accipitriformes indet. & 1 & 1 & & & & & & & & & 1 & 1 & 2 & 0.5 & 2 & 1.4 \\
\hline Alectoris rufa & 5 & 2 & & & 6 & 4 & 1 & 1 & 1 & 1 & 2 & 1 & 15 & 4.1 & 9 & 6.2 \\
\hline Coturnix coturnix & 5 & 2 & & & 1 & 1 & 1 & 1 & & & 4 & 2 & 11 & 3.0 & 6 & 4.1 \\
\hline Columba livia s. oenas & 9 & 3 & & & 5 & 3 & 2 & 2 & & & 5 & 2 & 21 & 5.7 & 10 & 6.8 \\
\hline Tyto alba & & & & & 1 & 1 & & & & & 1 & 1 & 2 & 0.5 & 2 & 1.4 \\
\hline Bubo bubo & & & & & & & & & & & 2 & 1 & 2 & 0.5 & 1 & 0.7 \\
\hline Athene noctua & 2 & 1 & & & 3 & 2 & & & & & 1 & 1 & 6 & 1.6 & 4 & 2.7 \\
\hline Strix aluco & & & & & 1 & 1 & & & & & & & 1 & 0.3 & 1 & 0.7 \\
\hline Apus apus & & & 1 & 1 & & & & & & & & & 1 & 0.3 & 1 & 0.7 \\
\hline Delichon urbica & & & & & & & & & & & 1 & 1 & 1 & 0.3 & 1 & 0.7 \\
\hline Anthus spinoletta & 1 & 1 & & & 2 & 1 & & & & & & & 3 & 0.8 & 2 & 1.4 \\
\hline Turdus viscivorus & & & & & 1 & 1 & & & & & & & 1 & 0.3 & 1 & 0.7 \\
\hline Emberiza calandra & 1 & 1 & & & 2 & 2 & & & & & & & 3 & 0.8 & 3 & 2.1 \\
\hline Fringilla coelebs & & & & & 1 & 1 & & & & & & & 1 & 0.3 & 1 & 0.7 \\
\hline Carduelis chloris & & & & & 1 & 1 & 1 & 1 & & & 1 & 1 & 3 & 0.8 & 3 & 2.1 \\
\hline Loxia pytyopsittacus & 1 & 1 & & & & & & & & & & & 1 & 0.3 & 1 & 0.7 \\
\hline Pinicola enucleator & & & 1 & 1 & & & & & & & & & 1 & 0.3 & 1 & 0.7 \\
\hline Pyrrhula pyrrhula & 1 & 1 & & & & & & & & & & & 1 & 0.3 & 1 & 0.7 \\
\hline Coccothraustes coccothraustes & 1 & 1 & & & 1 & 1 & & & & & 1 & 1 & 3 & 0.8 & 3 & 2.1 \\
\hline Sturnus sp. & & & & & & & & & & & 2 & 1 & 2 & 0.5 & 1 & 0.7 \\
\hline Pica pica & & & 1 & 1 & 1 & 1 & & & & & 3 & 1 & 5 & 1.4 & 3 & 2.1 \\
\hline Pyrrhocorax pyrrhocorax & 76 & 16 & 7 & 3 & 48 & 15 & 13 & 5 & & & 62 & 9 & 206 & 55.8 & 48 & 32.9 \\
\hline Pyrrhocorax graculus & 10 & 6 & 14 & 6 & 10 & 8 & & & & & 14 & 2 & 48 & 13.0 & 22 & 15.1 \\
\hline Corvus monedula & 8 & 4 & 2 & 2 & 2 & 2 & & & & & 8 & 4 & 20 & 5.4 & 12 & 8.2 \\
\hline Corvus corone & & & & & 1 & 1 & & & & & 1 & 1 & 2 & 0.5 & 2 & 1.4 \\
\hline Total & & & & & & & & & & & & & 369 & 100 & 146 & 100 \\
\hline
\end{tabular}


All of these data suggest that the Neanderthal populations that inhabited the surroundings of the Cova del Gegant lived in temperate summers $\left(-1.7^{\circ} \mathrm{C}\right)$ and harsher winters $\left(-5.3^{\circ} \mathrm{C}\right)$, but in a Mediterranean climate. In addition, the precipitations recorded support the presence of the porcupine, suggesting a slightly wetter climate in the area around the cave than nowadays. The small-vertebrate assemblage of Cova del Gegant may have been conditioned by taphonomy. According to Andrews [81], owls in particular may have been responsible for the accumulation of micromammals. Because this predator is opportunistic, their prey must reflect the local environmental conditions [82]. In support of this idea, it appears likely that the owl species responsible for the assemblage was a category 1 nocturnal bird of prey, based on a taphonomic bias that is not visible (primarily digesting evidence). In contrast, bats and porcupines are cave dwellers and their presence in the Cova del Gegant may be related to in-situ mortality rather than predator accumulation. This is a preliminary taphonomic study and the environmental inferences using small-mammals as a proxy should be interpreted with caution.

Table 5. Number of Identified Specimens (NISP) and Minimum Number of Individual (MNI) of the small vertebrates identified at GL1.

\begin{tabular}{|c|c|c|c|}
\hline & Taxon & NISP & MNI \\
\hline \multirow{6}{*}{ Amphibians } & Pelobates cultripes & 4 & 1 \\
\hline & Bufo gr. B. bufo & 4 & 2 \\
\hline & Epidalea calamita & 11 & 3 \\
\hline & Bufonidae indet. & 15 & 0 \\
\hline & Ranidae indet. & 2 & 1 \\
\hline & Anura indet. & 1 & 0 \\
\hline Testudines & Testudo hermanni & 20 & 2 \\
\hline \multirow{6}{*}{ Squamates } & Timon cf. lepidus & 2 & 1 \\
\hline & Malpolon monspessulanus & 10 & 1 \\
\hline & Zamenis scalaris & 14 & 1 \\
\hline & Colubrinae indet. & 2 & 0 \\
\hline & Vipera sp. & 2 & 1 \\
\hline & Ophidia indet. & 7 & 0 \\
\hline \multirow{4}{*}{ Insectivores } & Erinaceus europaeus & 1 & 1 \\
\hline & Sorex gr. coronatus-araneus & 6 & 4 \\
\hline & Crocidura russula & 10 & 9 \\
\hline & Talpa europaea & 2 & 1 \\
\hline \multirow{4}{*}{ Bats } & Rhinolophus ferrumequinum & 2 & 1 \\
\hline & Myotis myotis & 3 & 3 \\
\hline & Myotis sp. & 1 & 1 \\
\hline & Miniopterus schreibersii & 3 & 2 \\
\hline \multirow{9}{*}{ Rodents } & Microtus arvalis & 5 & 4 \\
\hline & Microtus agrestis & 5 & 4 \\
\hline & Microtus (Iberomys) cabrerae & 11 & 7 \\
\hline & Microtus (Terricola) duodecimcostatus & 12 & 9 \\
\hline & Microtus (Terricola) pyrenaicus & 2 & 2 \\
\hline & Apodemus sylvaticus & 69 & 29 \\
\hline & Eliomys quercinus & 15 & 6 \\
\hline & Hystrix (Acanthion) cf. brachyura-vinogradovi & 4 & 2 \\
\hline & Total & 245 & 98 \\
\hline
\end{tabular}


Table 6. Small mammal association of Cova del Gegant (left) in comparison with current small mammals that inhabit the Garraf Massif (right), according to Palomo et al. [83].

\begin{tabular}{|c|c|}
\hline Cova del Gegant & Currently at Garraf Massif \\
\hline \multicolumn{2}{|c|}{ Order Eulipotyphla } \\
\hline \multicolumn{2}{|l|}{ Erinaceus europaeus } \\
\hline \multicolumn{2}{|l|}{ Talpa europaea } \\
\hline Crocidura russula & Crocidura russula \\
\hline \multicolumn{2}{|l|}{ Sorex gr. coronatus -araneus } \\
\hline \multicolumn{2}{|c|}{ Order Rodentia } \\
\hline \multicolumn{2}{|l|}{ Hystrix (A.) cf. brachyura-vinogradovi } \\
\hline & Sciurus vulgaris \\
\hline & Arvicola sapidus \\
\hline \multicolumn{2}{|l|}{ Microtus arvalis } \\
\hline \multicolumn{2}{|l|}{ Microtus agrestis } \\
\hline \multicolumn{2}{|l|}{ Microtus (Iberomys) cabrerae } \\
\hline Microtus (Terricola) duodecimcostatus & Microtus (Terricola) duodecimcostatus \\
\hline \multicolumn{2}{|l|}{ Microtus (Terricola) pyrenaicus } \\
\hline \multirow[t]{5}{*}{ Apodemus sylvaticus } & Apodemus sylvaticus \\
\hline & Rattus rattus \\
\hline & Rattus norvegicus \\
\hline & Mus spretus \\
\hline & Mus musculus \\
\hline Eliomys quercinus & Eliomys quercinus \\
\hline
\end{tabular}

\subsection{Lithic Assemblage}

The lithic artifacts analysed present an intense white patina covering most or all of their surface; only two elements are unaltered. Moreover, three of them show evidence of edge damage in the form of microfractures, suggesting a post-depositional mechanical alteration. The less patinated artifacts correspond to four items wrapped in paper labelled as "from the Bronze Age", although all the lithics included in the 1974-1975 collection were previously considered Middle Palaeolithic. According to Mir [61], these artifacts were found in different stratigraphic units—one in unit I and three in unit IIb-and we do not know why they were labelled separately. These four pieces-one core-on-flake (Figure 8(10)), one denticulate (Figure 8(12)), one flake (Figure 8(11)) and one fragmented flake (Figure 9(2)) - are not considered as a part of the present study. The distribution of the remaining artifacts by size and the main lithic categories is presented in Table 7 .

Among the 26 remaining lithics, two cores have been identified. Both exhibit a welldefined reduction strategy. The first is a Levallois core showing a preferential flaking surface with mainly unidirectional detachments. Although some small removals were struck from the opposite direction, they seem designed to prepare the distal convexity. The opposite surface remains largely cortical, with the exception of the small proximal detachments used to prepare the striking platforms. In addition, the left edge of the preferential surface is retouched, which suggests that this core was secondarily used to manufacture a sidescraper. The second is a core-on-flake with bifacial removals and a typical discoid structure (Figure 9(4)). Both cores are characterised by a relatively large size $(65 \times 58 \times 15 \mathrm{~mm}$ and $56 \times 44 \times 20 \mathrm{~mm}$, respectively), which indicates that they were far from being exhausted. 

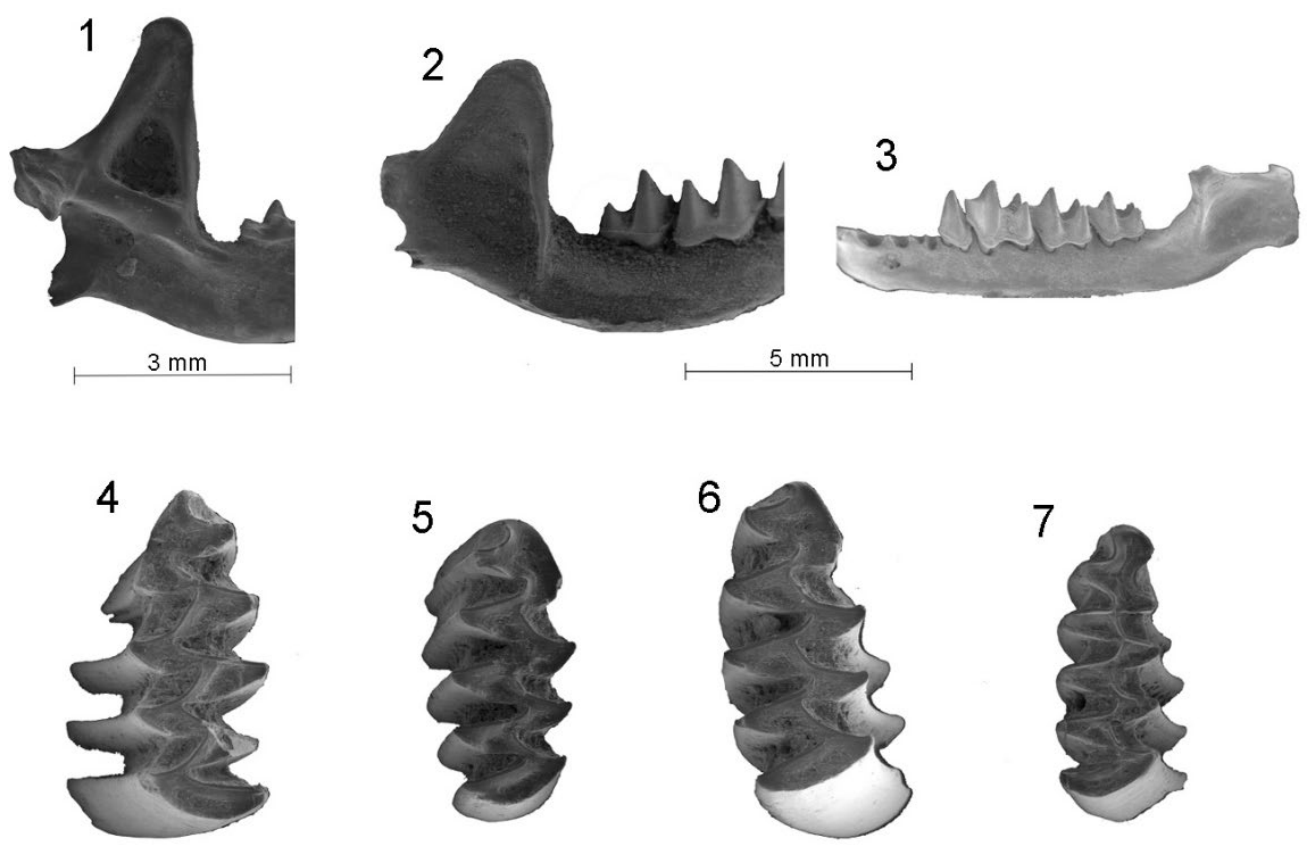

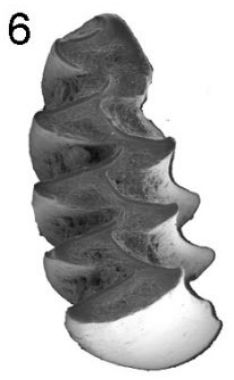

$2 \mathrm{~mm}$

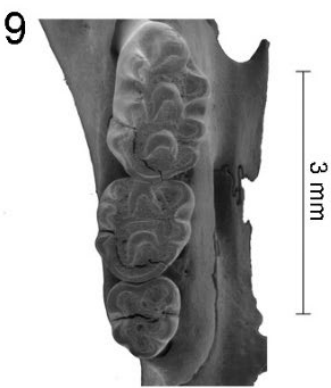

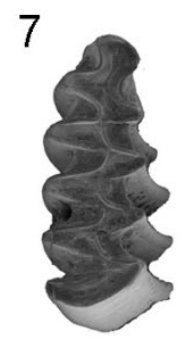

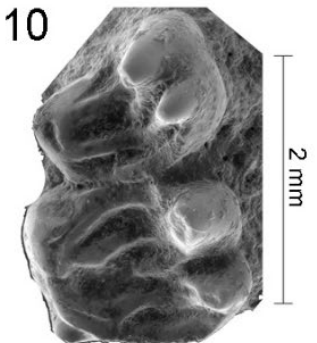

Figure 7. Some small mammal remains identified from Cova del Gegant. (1): Right mandible of Crocidura russula (lingual view). (2): Right mandible of Myotis myotis (buccal view). (3): Left mandible of Miniopterus schreibersii (buccal view). (4-6): One left, two right $\mathrm{m} 1$ of Microtus (Iberomys) cabrerae (occlusal view). (7): Right $\mathrm{m} 1$ of Microtus agrestis (occlusal view). (8): $\mathrm{m} 1$ right Microtus (Terricola) duodecimcostatus (occlusal view). (9): Right M1-M3 of Apodemus sylvaticus (occlusal view). (10): Left P4-M1 of Eliomys quercinus (occlusal view). ESEM (Environmental Scanning Electron Microscope) images of mandibles 1 to 3 showing diagnostic criteria for taxonomic identification.

Among the unretouched products, we identified eighteen complete flakes and three fragmented flakes. Among the complete products, very small and small flakes $(\mathrm{n}=14)$ are predominant, although large and very large ones are also represented $(n=4)$. There are no medium-sized flakes. In spite of the presence of a unidirectional Levallois core, no blades or elongated products have been documented. Only three flakes preserve cortical residues on their dorsal surfaces. The most striking platforms are flat and unprepared, but three dihedral and three facetted butts have been found. The presence of one Levallois flake (Figure 8(6)) and one pseudo-Levallois point (Figure 8(7)) should be noted. No naturally backed flakes have been identified. In general, asymmetrical products opposing an abrupt side to a cutting edge are scarce (only the pseudo-Levallois flake and the denticulate manufactured on a debordant flake can be included in this category).

Six retouched implements were identified: three lateral sidescrapers, one point and two denticulates. Different kinds of blanks were used to make these artifacts. One sidescraper (Figure 8(8)) suggesting a post-depositional mechanical alteration and the point (Figure 8(4)) were manufactured on Levallois blanks, one of them showing a faceted striking platform. 
Another sidescraper (Figure 8(5)) and the denticulates (Figures 8 and 9(15)) were on ordinary flakes and the third sidescraper was on a cortical flake (Figure 8(2)). The retouched artifacts were manufactured on medium-sized, large and very large flakes. There are two artifacts—one sidescraper (Figure 8(5)) and one denticulate (Figure 9(15)) — which, in addition to the retouched edges, show large removals on the ventral surface. In one case, the ventral removals postdated the formation of the white patina, indicating that this artifact was modified after a phase of abandonment (Figure 9(15)). These ventral removals have often been considered as actions aimed at removing the bulb and thinning the blanks. However, these artifacts can also be interpreted as representing an expedient exploitation of certain blanks to obtain a small number of flakes.

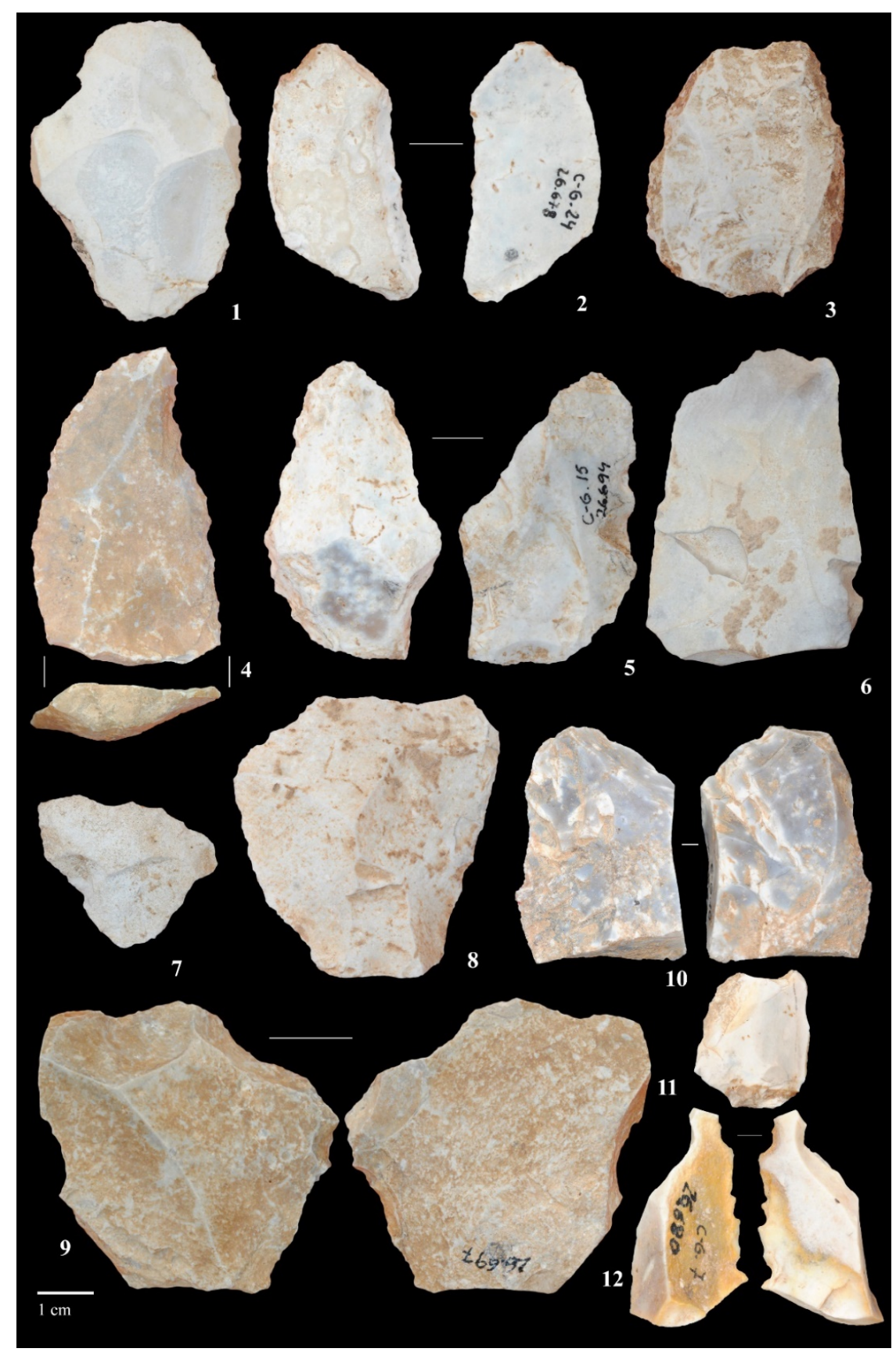

Figure 8. Lithic artifacts from Cova del Gegant. (1,3,11): Flake. (2,5,8): Sidescraper. (4): Point. (6): Levallois flake. (7): Pseudo-Levallois point. (9,12): Denticulate. (10): Core-on-flake. 


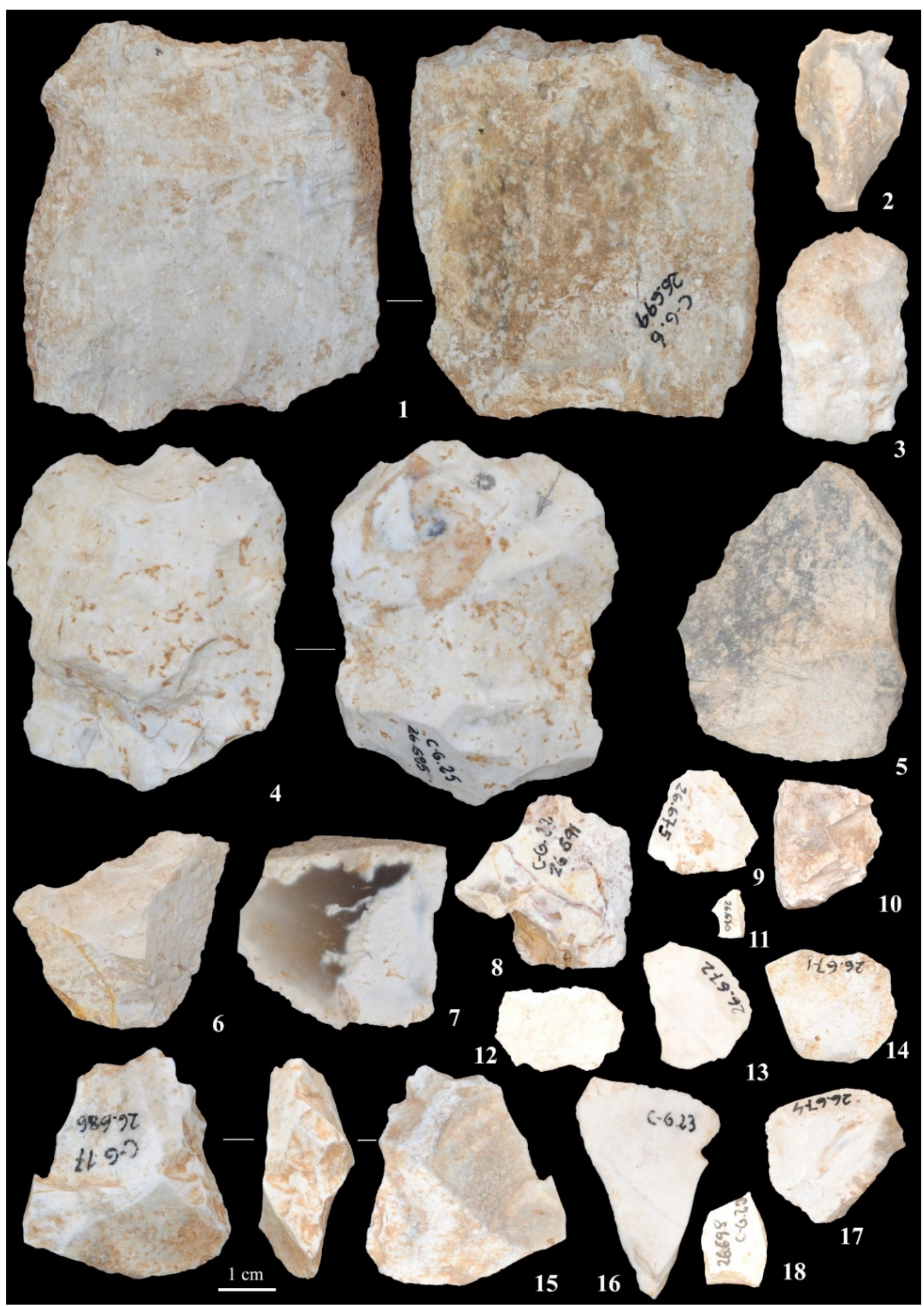

Figure 9. Lithic artifacts from Cova del Gegant. (1): Levallois core. (2,6,10,12): Flake fragment. $(\mathbf{3}, \mathbf{5}, \mathbf{7}-\mathbf{9}, \mathbf{1 1}, \mathbf{1 3}, \mathbf{1 4}, \mathbf{1 6}-18)$ : Flake. (4): Discoid core. (15). Denticulate. 
Table 7. Distribution of the artifacts according to technical and size categories.

\begin{tabular}{ccccccc}
\hline & $\begin{array}{c}\text { Very } \\
\text { Small }\end{array}$ & Small & Medium & Large & $\begin{array}{c}\text { Very } \\
\text { Large }\end{array}$ & Total \\
\hline Cores & & & & & 2 & 2 \\
Flakes & 6 & 8 & & 3 & 1 & 18 \\
$\begin{array}{c}\text { Flake fragments } \\
\text { Retouched artifacts }\end{array}$ & 2 & 1 & & & & 3 \\
$\quad$ Total & 8 & 9 & 3 & 1 & 2 & 6 \\
\hline
\end{tabular}

\section{Discussion}

\subsection{GL1 History and Correlation}

Cova del Gegant is one of the largest horizontal caves located on the Mediterranean sea board of the NE of the Iberian Peninsula. This cave presents a complex system of galleries and narrow passages containing lithics, faunal bones and anthropological remains. Previous studies have attempted to summarise the cave's chronological framework, based on the sedimentological profile preserved at the rear of the GP2 [6] and cemented remnants adhered to the cave bedrock [5]. These previous studies identified at least three main anthropogenic occupational episodes at the GP2, grouped between MIS 5 and MIS 3: (a) the earliest presence occurred between $\sim 93$ and $\sim 59 \mathrm{ka}$ and corresponds to short Middle Palaeolithic visits alternating with a hyena den, (b) the second presence occurred at around 43-39 ka in the form of sporadic fireplaces placed during the Châtelperronian/Aurignacian time period, and (c) the later presence occurred between $\sim 34$ and $~ 31$ ka during the Later Aurignacian/Gravettian. In this context, the Neanderthal human remains documented in the GP2 section are from layer Vf and could be dated between 72 and $67 \mathrm{ka}$. The second section with human presence is in the gallery described here (GL1).

However, the correlation between the two galleries is difficult because there is a large discontinuity without sediments s between GL1 and GP2 and the layers identified in both areas show significant variation. These variations are related with the distance from the source, i.e., the cave entrance, and the slope processes, which condition the amount of detrital elements present in the areas of the cave, thus implying significant intra-layer variation in grain size. In addition, the hard cementation of the sediments close to the sea, i.e., GL1, point $Y$ and GP1, contrast with the soft sediments of the rear of GP2 introducing colour alterations. Even so, the chronological range obtained from GL1 (49-65 ka) is consistent with that of layer V documented at GP2 and we propose to correlate the infilling preserved in this area with the sedimentation accumulated at the top of layer V. Assuming this correlation, the Middle Palaeolithic human remains, which are documented in layer Vf of the GP2 and XVb of GL1 of the cave, were accumulated over two periods during MIS 4 and MIS 3: the earliest fossils (Gegant-4 and Gegant-5) accumulated 72-67 ka (GP2) and additional remains (Gegant-1 and Gegant-2) were deposited 52 ka (GL1).

Cova del Gegant is now located in front of the sea. However, during the lowered sea levels of the Last Glacial Period (MIS 4-3-2) an extended continental platform emerged, permitting connectivity across the Mediterranean coast of the Iberian Peninsula. The entrance to Cova del Gegant, oriented towards the south, and the dimensions of the GP made the cave an attractive space for human and carnivore habitation. At the time of the Neanderthals, the main human occupation must have been located at the escarpmentfoot and at the cave entrance. The presence of a Levallois point in brecciated sediments adhered to the escarpment bedrock (Figure 2(5)) and located at the same altitude as GL1 reinforces the idea of external occupation eroded by sea wave action. Now, the original entrance is partially flooded and eroded by the sea, and a non-archaeological record has been observed in this area: only small-brecciated remnants adhered to the cave wall have been preserved. Being located 1.5 above the main chamber; GL1 was protected from sea erosion. However, the low ceiling and narrow dimensions would have meant that it was uninhabitable for hunter-gatherer groups. Infilling by a gravitational process may have 
been the main mechanism for the accumulation of layer $X V a / b$, which is located deep inside, and sediments accumulated at the cliff. Few lithics $(\mathrm{NR}=26)$ and human remains $(\mathrm{NR}=2)$ have been recovered in this gallery, probably due to the pattern of very short-term occupations. The absence of hearths, scarce thermoaltered bones $(\leq 1 \%)$ and the absence of cut-marks in the faunal assemblage reinforces the idea of very short occupation, slightly displaced along the sedimentation talus from the primary locus of deposition in the main gallery and/or in the entrance of the cave.

\subsection{GL1 Neanderthal Presence and Palaeoenvironmental Record}

No clear evidence of human action on the bones has been reported. Carnivore damage to ungulate bones observed in GL1, such as reduction of the epiphyses, furrows and other gnawing patterns, are in keeping with the pattern described for hyenas [84,85]. Differences in consumption patterns according to prey size are also observed, i.e., complete bones, such as metapodials, and bone cylinders are frequent for equids and large bovids; in contrast, broken shafts predominate in the medium-sized and small ungulate bones. However, the activity of other carnivores documented in GL1 cannot be totally ruled out.

This type of archaeological context-carnivore dens or trapped animals in caves with a few lithic remains-is common in the Iberian Middle Palaeolithic record [86-90] and identifying the nature of the anthropogenic processes carried out at the sites is a particularly challenging task. Some of the lithic assemblages recovered at these sites have been interpreted as the result of short visits by humans in the context of resource provisioning. However, it has also been suggested that, in some instances and especially in carnivore dens, lithic and faunal remains might be accidentally associated, since artifacts may have been moved into the caves by natural gravitational processes [91] or washed in [88]. In addition, we should bear in mind that archaeological assemblages tend to be comprised of large time-averaged palimpsests resulting from the outcome of an indeterminate, superimposed number of events occurring over a long time span [1,2]. The nature of these events may be diverse and there is no reason to expect that all of the remains were accumulated by the same agent and/or at the same time. Accordingly, several taphonomic signatures have been observed on faunal remains, such as well-preserved bones, bones in anatomical connection, or bones showing evidence of water erosion [13,45]. These are indicative of the agents and processes that occurred in the assemblage.

The origin of the human remains is difficult to discern. Neanderthal bones found in these contexts are usually isolated elements without articulation, which makes it difficult to relate them to intentional deposition or burial. During the Middle Palaeolithic, caves and rock shelters were occupied by both humans and carnivores and encounters between them are plausible. Several Neanderthal human remains show marks inflicted by carnivores, such as punctures, notches or gnawing marks [92]. The nature of these marks is difficult to distinguish; many of these fossil remains may have originated from carnivore predation of hominins, rather than intentional practices of corpse deposition, but the most common pattern of the taphonomic analyses are indicative of scavenging scenarios of Neanderthal corpses [93,94].

More controversial discussions surround the mortuary behaviour of the Middle Pleistocene European populations that evolved into Neanderthals. At least two major practices have been inferred: the treatment of corpses (cannibalism) $[95,96]$ and the accumulation of bodies in specifically designated places [97]. The presence of cranial fragments at GL1 and in the rear of GP2 may indicate that the skull was present, and probably the most parsimonious explanation for the accumulation of human remains could be related to disturbed burials, as proposed by other scholars [98]. However, the low number of skeletal elements and the lack of sediments in the entrance and in the main chamber of Cova del Gegant means that this interpretation should be considered with caution.

Concerning the lithic remains, the assemblage is another issue of the Neanderthal presence to be discussed. The small component of lithic remains suggests a marginal role of humans in the accumulation. This is consistent with the information provided by 
previous faunal remains studies $[13,45]$, which indicates that carnivores were the main agents responsible for the accumulation of bone assemblage. The absence of precise intrasite spatial distribution makes it difficult to assess this issue in more depth.

Our assessments are therefore based on post-depositional alterations and the distribution of lithics according to size and technical category. First, the intense white patina and the edge damage observed in some artifacts indicate that the lithics were affected by postdepositional processes. Although none of these alterations necessarily mean that the lithics were moved from elsewhere by natural agents, this scenario cannot be ruled out. Second, no size sorting is evident, as would be expected if natural dynamics were the main agent responsible for the accumulation. Both large and small artifacts are represented at Cova del Gegant, and the latter are dominant (Table 7), although they are less common than in records derived from knapping activities carried out on the spot. In this regard, we should consider that the excavation carried out in 1974-1975 applied a different methodology to the one used today and perhaps involved the occasional recovery of the smallest items.

Distribution by technical categories can provide additional clues on the formation dynamics of the lithic assemblage. The high proportion of retouched artifacts cannot be attributed to natural processes. This feature is not a bias of the recovery methods used during the 1974-1975 excavation because it was also observed in the 1985 campaign and during the current excavations developed at the GP2 section. Whatever the role played by postdepositional processes, they acted on an assemblage that had already been selected by humans, who mainly transported retouched implements into the site. Moreover, we should bear in mind that the artifacts were found in a lateral gallery (GL1), but the deposits from the main gallery (GP) were eroded by sea waves. The GP and, particularly, the zone close to the cave entrance was probably the area that was most suitable for human occupation, as previously mentioned. For this reason, we cannot rule out the idea that artifacts found in GL1 were related to hypothetical knapping activities carried out in these living areas and that we are therefore dealing with a marginal sample of a larger assemblage. As highlighted in other Palaeolithic contexts [99], the lithic assemblages found in the outer and more illuminated areas of caves can be very different from those found in the inner and darker areas. In fact, the human occupation of the cave has been confirmed by a hearth found in the innermost area of the main gallery of Cova del Gegant (GP2) [32], which strengthens the probability of more substantial human inputs in the outer zone.

Even so, considering the assemblage found in GL1, it seems clear that knapping activities were very restricted in this cave area. However, the presence of cores and small/very small flakes suggest that some limited knapping events were carried out. The distribution of flakes by size shows a marked discontinuity between the small/very small and the large/very large items due to the absence of medium-sized products. This feature indicates that these products correspond to two different reduction sequences and were associated with two different inputs. The large and very large flakes, together with the retouched artifacts, tend to be part of mobile toolkits and were therefore introduced into the sites as single items [86,100-102]. These two components-the transported vs. the locally produced artifacts-can be recognised in most cases and the balance between them determines many characteristics of the lithic assemblages. In Cova del Gegant, the transported artifacts are highly visible due to the limited role played by on-site production.

The archaeological record from the GL1 gallery helps to reconstruct the environmental conditions of Neanderthal populations and the occupational patterns. The faunal assemblage is composed of a rich collection of large mammals, birds and small vertebrates. It reflects diverse habitats and thus suggests either the presence of a complex environment or a large catchment area. This is relevant for the bird species and for the small vertebrates living in Mediterranean woodland edges and other taxa more typical of open environments. The large mammal record suggests an open landscape and, together with the absence of marine taxa, indicates that a littoral platform emerged in front of the cave. Thus, the cave mouth would have opened onto a large plain that could sustain and feed large herbivores, such as horses, proboscideans and large bovids. The presence of Equus hydruntinus in GL1 
supports this idea of the landscape and also indicates an arid and open terrain [103-105]. Red deer, which are also abundant in the assemblage, are intermediate feeders, but can feed on grasses or in light forests. Forest dwellers are also present, such as wild boar, ibex, small vertebrates and some birds, such as greenfinch, parrot crossbill, pine grosbeak, bullfinch and hawfinch. The presence of porcupine has been discussed elsewhere [106]; those authors suggest that these remains located at the top of GL1 may have been re-elaborated from other layers. Based on the small vertebrate proxies, the environmental conditions of the GL1 assemblage suggest lower temperatures $\left(-2.7^{\circ} \mathrm{C}\right)$ than at present in the same area, with temperate summers $\left(-1.7^{\circ} \mathrm{C}\right)$ and harsher winters $\left(-5.3^{\circ} \mathrm{C}\right)$. However, there is nothing in the composition of the faunal assemblage to indicate the presence of a marine component. The only taxon related to this environment corresponds to a single bone of Manx shearwater, possibly from a specimen breeding in the soft sediments of the cave floor. The avian record is dominated by species adapted to open landscapes. In terms of MNI, the red-billed and yellow-billed choughs represent together $48 \%$ of the total. This is a species adapted to rocky environments.

\subsection{Cova Del Gegant in the Regional Context}

The regional context of Cova del Gegant comprises a rich set of archaeo-palaeontological record characterised by small lithics with a huge amount of faunal remains accumulated by carnivores or natural agents. In this local context, Cova del Rinoceront and Cova del Coll Verdaguer, 15 and $20 \mathrm{~km}$ respectively from Cova del Gegant, exhibit rather different lithic assemblages, reflecting the variability that can be discerned in what Brugal and Jaubert [107] defined as "palaeontological sites with scarce human presence". Cova del Rinoceront was used as a carnivore den (layers I and II) and was a natural trap (III to VII) [108], but no evidence of human activity was documented on bones [83]. Only 22 artifacts were recovered, and very small items were clearly dominant. This evidence of size sorting, together with the edge damage shown in most artifacts, suggested that lithics may have been dragged in by post-depositional processes.

Cova del Coll Verdaguer yielded a rich faunal assemblage, mainly accumulated by hyenas that used the cave as a den, although the role of other carnivores is present $[89,109]$. Fourteen lithics were documented and very small artifacts are represented only by two flake fragments. The rest of the assemblage was characterised by high volumetric variability, including small $(n=5)$, medium $(n=4)$, large $(n=2)$ and very large $(n=1)$ flakes. Six of these flakes exhibited asymmetrical cross-sectional profiles, opposing a cutting edge to an abrupt back. This feature may suggest that the items in the assemblage were selected, and that the accumulation was related to the human transport of single artifacts. In marked contrast to Cova del Gegant, neither cores nor retouched artifacts were found in Cova del Coll Verdaguer. Some knapping was identified through refitting.

The comparison between Cova del Gegant and Cova del Coll Verdaguer is also significant in terms of the criteria used to select the mobile toolkit, since both assemblages are largely made up of transported single items. In spite of the constraints on mobility and transport common to both sites, the artifacts from Cova del Gegant and Cova del Coll Verdaguer exhibit clear differences. The first is the high frequency of retouched tools in Cova del Gegant and their absence in Coll Verdaguer. Second, artifacts with an asymmetrical cross-sectional profile (naturally backed flakes, debordant flakes, pseudo-Levallois points) are common in Cova del Coll Verdaguer, but scarce in Gegant. This suggests that the occupants of Cova del Coll Verdaguer were more concerned with selecting this kind of blanks, whose ergonomic properties have been emphasised [110]. There are also some technological differences, even though the assemblages are too small to carry out a thorough assessment of the reduction strategies. The use of the Levallois method is clear in Cova del Gegant, where a typical Levallois core and at least three Levallois blanks have been documented, but less evident in Cova del Coll Verdaguer. These differences emphasise the behavioural variability associated with artifact transport and the range of options available to Neandertal groups facing similar challenges in similar environmental settings. 


\section{Conclusions}

The GL1 of Cova del Gegant provides a good archive for evaluating the environmental conditions of coastal areas during MIS 4 and MIS 3 in the NE of Iberian Peninsula. The vertebrate record, comprising $~ 70$ taxa of faunal remains, is indicative of the richness and diversity of species and providing a clear picture of a period between 49 and $65 \mathrm{ka}$ in the Mediterranean coast. The palaeoenvironmental reconstruction presented here suggests that an open landscape dominated the vicinity of Cova del Gegant close to woodland areas, in agreement with previous studies and palaeoenvironmental reconstructions in the NE of the Iberian Peninsula. The absence of marine elements at GL1 is notable and suggests the development of a large coastal platform during the cold climatic periods due to lower sea levels and plain bathymetric curves. Thus, the cave entrance was roughly 7-9 km further from the coastline than today.

The low level of human activity observed at GL1 may indicate that the site was a brief stopping-place used by highly mobile Neanderthal hunter-gatherer groups. The age-at-death of Neanderthal individuals from Cova del Gegant, not restricted to adults, may suggest that the cave was used as a short stop during residential mobility involving all the group (i.e., all ages). Indeed, the lithics from GL1 seem to be part of a mobile toolkit rather than instruments used for knapping and manufacturing activities at the cave. The absence of butchering or other domestic activities supports this idea. Thus, it seems plausible that the Neanderthal remains from GL1 could be the result of repeated visits when groups halted in their camp-to-camp displacements along this coastal platform, rather than the result of hunting parties or groups procuring raw materials. Indeed, the regional context presents evidence of a wide variability in habitat types, site occupation, environmental conditions, intensity and geographic settings. This knowledge of the local resources supports the idea that subsistence strategies of the Neanderthal groups involved a certain amount of forward planning.

Supplementary Materials: The following supporting information can be downloaded at: https: / / www.mdpi.com/article/10.3390/quat5010012/s1, Figure S1: The 3d model of Cova del Gegant mandible (Gegant-1).

Author Contributions: J.D. and M.S. conceived the manuscript, designed the research, and conducted current excavations. J.D. and M.S. wrote the manuscript with contributions from other authors (J.D. stratigraphy and chronology, M.V. lithics; M.S. large mammals; J.M.L.-G. and H.-A.B. small vertebrates, A.S.M. birds). All authors have read and agreed to the published version of the manuscript.

Funding: This research received no external funding.

Institutional Review Board Statement: Not applicable.

Informed Consent Statement: Not applicable.

Acknowledgments: This study is part of the output of a research project entitled: "Els canvis climàtics durant el plistocè superior a la costa central catalana i l'impacte en les poblacions neandertals i humans anatòmicament moderns" (CLT009/18/00022-Generalitat de Catalunya), supported by projects 2017SGR-00011 (Generalitat de Catalunya) and PID2020-113960GB-100 (Ministerio de Ciencia e Innovación). J. Daura holds a Ramon y Cajal contract (RYC-2015-17667). M. Sanz was supported by a Juan de la Cierva postdoctoral grant (IJCI-2017-33908). Thanks to the Castelldefels City Council (La Guixera Laboratory) where the archaeological analyses were carried out. We extend our thanks to I. Bergamnn for photographic documentation of Neanderthal mandible images and $3 \mathrm{~d}$ model. We are grateful to the staff of the Museu d'Arqueologia de Catalunya (MAC), Museu de Geologia de Barcelona (MGB) and Arxiu Històric de Sitges (AHS) for their assistance during the study of the materials analysed here. This research was supported by the 2017-SGR-836 and 2017-SGR-859 projects of the Catalonian Government and the French International Research Network (IRN 0871 CNRS-INEE): Taphonomy European Network (TaphEN). J.M.L.-G. was supported by a Ramon y Cajal contract (RYC-2016-19386) from the Spanish Ministry of Science and Innovation. ASM has been supported by the project CGL2016-76431-P and CGL2017-82654-P (AEI/FEDER, EU). 
Conflicts of Interest: The authors declare no conflict of interest.

\section{References}

1. Bailey, G. Time Perspectives, Palimpsests and the Archaeology of Time. J. Anthropol. Archaeol. 2007, 26, 198-223. [CrossRef]

2. Bailey, G.; Galanidou, N. Caves, Palimpsests and Dwelling Spaces: Examples from the Upper Palaeolithic of South-East Europe. World Archaeol. 2009, 41, 215-241. [CrossRef]

3. Stiner, M.C. The Faunas of Hayonim Cave, Israel: A 200,000-Year Record of Paleolithic Diet, Demography, and Society; Harvard University Press: Cambrige, MA, USA, 2005.

4. Daura, J.; Sanz, M.; Oms, F.X.; Pedro, M.; Martínez, P.; Mendiela, S.; Oliva Poveda, M.; Gibaja, J.F.; Mozota, M.; Alonso-Eguíluz, M.; et al. Deciphering Neolithic Activities from a Cardial Burial Site (Cova Bonica) on the Western Mediterranean Coast. J. Archaeol. Sci. Rep. 2019, 23, 324-347. [CrossRef]

5. Daura, J.; Sanz, M.; Pike, A.W.G.; Subirà, M.E.; Fornós, J.J.; Fullola, J.M.; Julià, R.; Zilhão, J. Stratigraphic Context and Direct Dating of the Neandertal Mandible from Cova Del Gegant (Sitges, Barcelona). J. Hum. Evol. 2010, 59, 109-122. [CrossRef] [PubMed]

6. Daura, J.; Sanz, M.; Demuro, M.; Arnold, L.J.; Costa, A.M.; Moreno, J.; Freitas, M.C.; Lopes, V.; Égüez, N.; Hoffman, D.L.; et al. A New Chronological Framework and Site Formation History for Cova Del Gegant (Barcelona): Implications for Neanderthal and Anatomically Modern Human Occupation of NE Iberian Peninsula. Quat. Sci. Rev. 2021, 270, 107-141. [CrossRef]

7. Daura, J.; Sanz, M.; Subirá, M.E.; Quam, R.; Fullola, J.M.; Arsuaga, J.L. A Neandertal Mandible from the Cova Del Gegant (Sitges, Barcelona, Spain). J. Hum. Evol. 2005, 49, 56-70. [CrossRef] [PubMed]

8. Rodríguez, L.; García-González, R.; Sanz, M.; Daura, J.; Quam, R.; Fullola, J.M.; Arsuaga, J.L. A Neanderthal Lower Incisor from Cova Del Gegant (Sitges, Barcelona, Spain). Bol. R. Soc. Esp. Hist. Nat. Sec. Geol. 2011, 105, 25-30.

9. Arsuaga, J.L.; Quam, R.; Daura, J.; Sanz, M.; Subira, M.E.; Dalén, L.; Götherström, A. Neandertal MtDNA from a Late Pleistocene Human Mandible from the Cova Del Gegant (Spain). In Vertebrate Paleobiology and Paleoanthropology; Springer: Dordrecht, The Netherlands, 2011; pp. 213-217. [CrossRef]

10. Sanz, M. Patrons d'acumulació de Restes de Fauna Del Plistocè Superior Al Nord-Est Peninsular (Àrea Del Massís Del GarrafOrdal). Ph.D. Thesis, Universitat de Barcelona, Barcelona, Spain, 2013.

11. Daura, J.; Sanz, M. Procedencia Estratigráfica de Los Restos Humanos Neandertales de La Cova Del Gegant (Sitges, Barcelona). Mainake 2011, 33, 215-232.

12. Samper, S.C. Who Let the Hyenas Out? Taphonomic Analysis of the Faunal Assemblage from Upper Pleistocene Site of Cova Del Gegant (Sitges, Spain); The University of Edinburg: Edinburg, Scotland, 2011.

13. Sanz, M.; Daura, J. La Fauna Del Pleistoceno Superior Asociada a Los Restos Humanos Neandertales de La Galería Lateral 1 de La Cova Del Gegant (Sitges, Barcelona). SAGVNTVM 2020, 20, 81-98.

14. Arsuaga, J.L.; Martinez, I.; Arnold, L.J.; Aranburu, A.; Gracia-Tellez, A.; Sharp, W.D.; Quam, R.M.; Falgueres, C.; Pantoja-Perez, A.; Bischoff, J.; et al. Neandertal Roots: Cranial and Chronological Evidence from Sima de Los Huesos. Science 2014, 344, 1358-1363. [CrossRef]

15. Meyer, M.; Arsuaga, J.-L.; de Filippo, C.; Nagel, S.; Aximu-Petri, A.; Nickel, B.; Martínez, I.; Gracia, A.; de Castro, J.M.B.; Carbonell, E.; et al. Nuclear DNA Sequences from the Middle Pleistocene Sima de Los Huesos Hominins. Nature 2016, 531, 504-507. [CrossRef]

16. Zilhão, J. The Late Persistence of the Middle Palaeolithic and Neandertals in Iberia: A Review of the Evidence for and against the "Ebro Frontier" Model. Quat. Sci. Rev. 2021, 270, 107098. [CrossRef]

17. Zilhão, J.; Angelucci, D.E.; Igreja, M.A.; Arnold, L.J.; Badal, E.; Callapez, P.; Cardoso, J.L.; D’Errico, F.; Daura, J.; Demuro, M.; et al. Last Interglacial Iberian Neandertals as Fisher-Hunter-Gatherers. Science 2020, 367, eaaz7943. [CrossRef]

18. Quam, R.; Sanz, M.; Daura, J.; Robson Brown, K.; García-González, R.; Rodríguez, L.; Dawson, H.; Rodríguez, R.F.; Gómez, S.; Villaescusa, L.; et al. The Neandertals of Northeastern Iberia: New Remains from the Cova Del Gegant (Sitges, Barcelona). J. Hum. Evol. 2015, 81, 13-28. [CrossRef]

19. Salas, R. El Malm i El Cretaci Inferior Entre El Massís Del Garraf i La Serra dEspadà. PhD Thesis, Universitat de Barcelona, Barcelona, Spain, 1987.

20. Daura, J.; Sanz, M.; Fornós, J.; Asensio, A.; Julià, R. Karst Evolution of the Garraf Massif (Barcelona, Spain): Doline Formation, Chronology and Archaeo-Palaeontological Archives. J. Cave Karst Stud. 2014, 76, 69-87. [CrossRef]

21. Marqués, M.A.; Julià, R. Geomorphological Mapping of Mediterranean Coastal Features, Northeast Spain. J. Coast. Res. 1987, 3 , 29-36.

22. Daura, J.; Sanz, M.; Ramos, J.; Riera, S.; Miras, Y.; Allué, E.; Picornell-Gelabert, L.; López-Reyes, D.; Albert, R.M.; Macià, L.; et al. Palaeoenvironmental Record of the Cal Maurici Wetland Sediment Archive in Barcelona (NE Iberian Peninsula) between c. 6000 and 4000 Cal. Yr BP. Holocene 2016, 26, 1020-1039. [CrossRef]

23. Virella, A. Vilanova i La Geltrú. Imatges de La Ciutat i de La Comarca; Joan Rius Vila: Vilanova i la Geltrú, Spain, 1949.

24. Daura, J.; Sanz, M. Nota Necrológica: Santiago Casanova i Giner (Forcall 1922-Barcelona 2011). Cypsela 2017, 20 , 7-8.

25. Viñas, R.; Villalta, J. El Depósito Cuaternario de La "Cova Del Gegant." In Speleon V Symposium de Espeleología; Centre Excursionista Catalunya: Barcelona, Spain, 1975; pp. 19-33.

26. Viñas, R. Observaciones Sobre Los Depósitos Cuaternarios de La Cova Del Gegant. Sitges (Barcelona). Speleon 1972, 19, 115-126. 
27. Bellmunt, J. Crónica de La Sección Arqueológica. Boletín Bibl. -Mus. Balaguer 1958, 5, 132-134.

28. Martínez-Moreno, J.; Miret, J.; Mora, R.; Muro, I. Excavacions a La Cova Del Gegant. Butlletí d'estudis Sitgetans 1985, $32-33,1$.

29. Martínez-Moreno, J. Informe Técnico de Los Restos Óseos de La Cova Del Gegant (Sitges, Garraf). Servei d'Arqueologia i Paleontologia; Centre d'Informació i Documentació del Patrimoni Cultural de la Generalitat de Catalunya: Barcelona, Spain, 1990.

30. Martínez-Moreno, J.; Mora, R.; Roca, G.; Parcerisas, J. Memoria d’Excavació a La Cova Del Gegant 1989. Servei d'Arqueologia $i$ Paleontologia; Centre d'Informació i Documentació del Patrimoni Cultural de la Generalitat de Catalunya: Barcelona, Spain, 1990.

31. Martínez-Moreno, J.; Mora Torcal, R.; Muro Morales, I.; Miret i Mestre, J. Memòria de l'excavació d'urgència de La Cova Del Gegant (Sitges, Garraf) 1985; Centre d'Informació i Documentació del Patrimoni Cultural de la Generalitat de Catalunya: Barcelona, Spain, 1985.

32. Sanz, M.; Daura, J.; Égüez, N.; Cabanes, D. On the Track of Anthropogenic Activity in Carnivore Dens: Altered Combustion Structures in Cova Del Gegant (NE Iberian Peninsula). Quat. Int. 2017, 437, 102-114. [CrossRef]

33. Bischoff, J.L.; Julia, R.; Mora, R. Uranium-Series Dating of the Mousterian Occupation at Abric Romani, Spain. Nature 1988, 332, 68-70. [CrossRef]

34. Rosenbauer, R.J. UDATE1: A Computer Program for the Calculation of Uranium-Series Isotopic Ages. Comput. Geosci. 1991, 17, 45-75. [CrossRef]

35. Hoffmann, D.L.; Pike, A.W.G.; García-Diez, M.; Pettitt, P.B.; Zilhão, J. Methods for U-Series Dating of CaCO3 Crusts Associated with Palaeolithic Cave Art and Application to Iberian Sites. Quat. Geochronol. 2016, 36, 104-119. [CrossRef]

36. Hoffmann, D.L. 230Th Isotope Measurements of Femtogram Quantities for U-Series Dating Using Multi Ion Counting (MIC) MC-ICPMS. Int. J. Mass Spectrom. 2008, 275, 75-79. [CrossRef]

37. Hoffmann, D.L.; Prytulak, J.; Richards, D.A.; Elliott, T.; Coath, C.D.; Smart, P.L.; Scholz, D. Procedures for Accurate U and Th Isotope Measurements by High Precision MC-ICPMS. Int. J. Mass Spectrom. 2007, 264, 97-109. [CrossRef]

38. Hoffmann, D.L.; Standish, C.D.; García-Diez, M.; Pettitt, P.B.; Milton, J.A.; Zilhão, J.; Alcolea-González, J.J.; Cantalejo-Duarte, P.; Collado, H.; de Balbín, R.; et al. U-Th Dating of Carbonate Crusts Reveals Neandertal Origin of Iberian Cave Art. Science 2018, 359, 912-915. [CrossRef]

39. Millard, A.R.; Hedges, R.E.M. A Diffusion-Adsorption Model of Uranium Uptake by Archaeological Bone. Geochim. Et Cosmochim. Acta 1996, 60, 2139-2152. [CrossRef]

40. Pike, A.W.G.; Eggins, S.; Grün, R.; Hedges, R.E.M.; Jacobi, R.M. U-Series Dating of the Late Pleistocene Mammalian Fauna from Wood Quarry (Steetley), Nottinghamshire, UK. J. Quat. Sci. 2005, 20, 59-65. [CrossRef]

41. Valero-Garcés, B.L.; González-Sampériz, P.; Gil-Romera, G.; Benito, B.M.; Moreno, A.; Oliva-Urcia, B.; Aranbarri, J.; García-Prieto, E.; Frugone, M.; Morellón, M.; et al. A Multi-Dating Approach to Age-Modelling Long Continental Records: The 135 Ka El Cañizar de Villarquemado Sequence (NE Spain). Quat. Geochronol. 2019, 54, 101006. [CrossRef]

42. Aitken, M.J. Thermoluminescence Dating; Academic Press: London, UK, 1985.

43. Nambi, K.S.V.; Aitken, M.J. Annual Dose Conversion Factors for TL and ESR Dating. Archaeometry 1986, 28, 202-205. [CrossRef]

44. Santafé, J.V.; Casanovas, M.L. Dicherorhinus hemitoechus (Falconer, 1868) (Mammalia, Perissodactyla) Del Yacimiento Pleistocénico de La Cueva Del Gegant (Garraf, Barcelona). Empúries Rev. Món Clàssic Antig. Tardana 1989, 48-50, 310-322.

45. Samper Carro, S.C.; Martínez-Moreno, J. Who Let the Hyenas out? Taphonomic Analysis of the Faunal Assemblage from GL-1 of Cova Del Gegant (Sitges, Spain). Quat. Int. 2014, 330, 19-35. [CrossRef]

46. Reitz, E.J.; Wing, E.S. Zooarchaeology; Cambridge University Press: Cambridge, UK, 2008.

47. Poplin, F. Un Problème d'ostéologie Quantitative: Calcul d'effectif Initial d'après Appariements. Généralisation Aux Autres Types de Remontages et à d'autres Matériels Archéologiques. Rev. D'archéométrie 1981, 5, 159-165. [CrossRef]

48. Lyman, R.L. Quantitative Paleozoology; Cambridge University Press: Cambridge, UK, 2008. [CrossRef]

49. Brain, C.K. The Hunters or the Hunted?: An Introduction to African Cave Taphonomy; University of Chicago Press: Chicago, CA, USA, 1981.

50. Lyman, R.L. Vertebrate Taphonomy; Cambridge University Press: Cambridge, UK, 1994. [CrossRef]

51. Fernández-Jalvo, Y.; Andrews, P. Atlas of Taphonomic Identifications; Vertebrate Paleobiology and Paleoanthropology; Springer: Dordrecht, The Netherlands, 2016. [CrossRef]

52. Johnson, E. Current Developments in Bone Technology. In Advances in Archaeological Method and Theory; Elsevier: Amsterdam, The Netherlands, 1985; pp. 157-235. [CrossRef]

53. Blumenschine, R.J.; Selvaggio, M.M. Percussion Marks on Bone Surfaces as a New Diagnostic of Hominid Behaviour. Nature 1988, 333, 763-765. [CrossRef]

54. Haynes, G. A Guide for Differentiating Mammalian Carnivore Taxa Responsible for Gnaw Damage to Herbivore Limb Bones. Paleobiology 1983, 9, 164-172. [CrossRef]

55. Fosse, P.; Avery, G.; Selva, N.; Smietana, W.; Okarma, H.; Wajrak, A.; Fourvel, J.B.; Madelaine, S. Taphonomie Comparée Des Os Longs d'ongulés Dévorés Par Les Grands Prédateurs Modernes d’Europe et d'Afrique (C. Lupus, P. Brunnea). In Prédateurs dans tous leurs états. Evolution, Biodiversité, Interactions, Mythes, Symboles. XXXIe Rencontres Internationales d'Archéologie et d'Histoire d'Antibes; Brugal, J.-P., Gardeisen, A., Zucker, A., Eds.; APDCA: Antibes, France, 2011; pp. 127-156.

56. Behrensmeyer, A.K. Taphonomic and Ecologic Information from Bone Weathering. Paleobiology 1978, 4, 150-162. [CrossRef]

57. Blain, H.-A.; Bailon, S. Catalogue of Spanish Plio-Pleistocene Amphibians and Squamate Reptiles from the Museu de Geologia de Barcelona. Treb. Mus. Geol. Barc. 2006, 14, 61-80. 
58. López-García, J.M.; Agustí, J.; Cuenca-Bescós, G. Catalogue of the Late Quaternary Iberian Micromammals (Rodentia, Eulipothypla, Chiroptera) from the Museu de Geologia de Barcelona. Treb. Mus. Geol. Barc. 2007, 15, 5-23.

59. López-García, J.M.; Blain, H.-A.; Cuenca-Bescós, G.; Arsuaga, J.L. Chronological, Environmental, and Climatic Precisions on the Neanderthal Site of the Cova Del Gegant (Sitges, Barcelona, Spain). J. Hum. Evol. 2008, 55, 1151-1155. [CrossRef]

60. Sánchez Marco, A. Avifaunas Cuaternarias de La Península Ibérica: Sistemática, Paleocologia, Paleozoografia. Ph.D. Thesis, Universidad Autónoma de Madrid, Madrid, Spain, 2005.

61. Mir, A. La Industria Lítica de La Cova Del Gegant. Sitges (Barcelona). Speleon. Monogr. I. V Symp. Espeleol. 1975, $39-48$.

62. Mora, R. El Paleolítico Medio En Catalunya: Yacimientos En Cueva y Al Aire Libre. Ph.D. Thesis, Unversitat de Barcelona, Barcelona, Spain, 1988.

63. Laplace, G. La Typologie Analytique et Structurale. Base Rationalle d'étude Des Industries Lithiques et Osseuses. In Branques des Données Archéologiques; Centre National de la Recherche Scientifique: Paris, France, 1974; pp. 91-143.

64. Gómez-Alba, J. Catálogo Razonado de Los Vertebrados Fósiles de España Del Museo de Geología de Barcelona (1882-1982). Treb. Mus. Geol. Barc. 1997, 6, 1-296.

65. Daura, J.; Sanz, M. Historiografia Dels Jaciments Plistocens Al Massís Del Garraf i Curs Baix Del Riu Llobregat. Treb. Mus. Geol. Barc. 2009, 16, 5-38.

66. Masriera, A. Observaciones Sedimentológicas Sobre El Depósito Cuaternario de La Cova Del Gegant (Sitges, Barcelona). Speleon V Symposium de Espeleología; Centre Excursionista de Catalunya: Barcelona, Spain, 1975; pp. 35-38.

67. Jaffey, A.H.; Flynn, K.F.; Glendenin, L.E.; Bentley, W.C.; Essling, A.M. Precision Measurement of Half-Lives and Specific Activities of 235U and 238U. Phys. Rev. C 1971, 4, 1889. [CrossRef]

68. Cheng, H.; Edwards, R.L.; Hoff, J.; Gallup, C.D.; Richards, D.A.; Asmerom, Y. The Half-Lives of Uranium-234 and Thorium-230. Chem. Geol. 2000, 169, 17-33. [CrossRef]

69. Holden, N.E. Total Half-Lives for Selected Nuclides. Pure Appl. Chem. 1990, 62, 941-958. [CrossRef]

70. Discamps, E. Ungulate Biomass Fluctuations Endured by Middle and Early Upper Paleolithic Societies (SW France, MIS 5-3): The Contributions of Modern Analogs and Cave Hyena Paleodemography. Quat. Int. 2014, 337, 64-79. [CrossRef]

71. Hammer, Ø.; Harper, D.A.T.; Ryan, P.D. Past: Paleontological Statistics Software Package for Education and Data Analysis. Palaeontol. Electron. 2001, 4, 1-9.

72. Sánchez Marco, A. Avian Zoogeographical Patterns during the Quaternary in the Mediterranean Region and Paleoclimatic Interpretation. Ardeola 2004, 51, 91-132.

73. Sánchez Marco, A. Avifauna de La Peña de Estebanvela (Segovia). In La Peña de Estebanvela: Grupos Magdalenienses en el Sur del Duero; Cacho, C., Ripoll, S., Muñoz, F.J., Eds.; Arqueología en Castilla y León 17; Arqueología en Castilla y León; Consejería de Cultura y Turismo de la Junta de Castilla y León: Valladolid, Spain, 2007; pp. 141-144.

74. Tyrberg, T. Pleistocene Birds of the Palearctic: A Catalogue; Mass: Cambridge, MA, USA, 1998; Volume 27.

75. Díaz, M.; Asensio, B.; Tellería, J.L. Aves Ibéricas: I. No Paseriformes.; Reyero, J.M., Ed.; Reyero, J.M.: Madrid, Spain, 1996.

76. Tellería, J.L.; Asensio, B.; Díaz, M. Aves Ibéricas: II. Paseriformes; Reyero, J.M., Ed.; Reyero, J.M.: Madrid, Spain, 1999.

77. Blanco, G.; Sánchez-Marco, A.; Negro, J.J. Night Capture of Roosting Cave Birds by Neanderthals: An Actualistic Approach. Front. Ecol. Evol. 2021, 9, 9. [CrossRef]

78. Blain, H.-A.; Bailon, S.; Cuenca-Bescós, G.; Arsuaga, J.L.; Bermúdez de Castro, J.M.; Carbonell, E. Long-Term Climate Record Inferred from Early-Middle Pleistocene Amphibian and Squamate Reptile Assemblages at the Gran Dolina Cave, Atapuerca, Spain. J. Hum. Evol. 2009, 56, 55-65. [CrossRef] [PubMed]

79. Blain, H.-A.; Lozano-Fernández, I.; Agustí, J.; Bailon, S.; Menéndez Granda, L.; Espígares Ortiz, M.P.; Ros-Montoya, S.; Jiménez Arenas, J.M.; Toro-Moyano, I.; Martínez-Navarro, B.; et al. Refining upon the Climatic Background of the Early Pleistocene Hominid Settlement in Western Europe: Barranco León and Fuente Nueva-3 (Guadix-Baza Basin, SE Spain). Quat. Sci. Rev. 2016, 144, 132-144. [CrossRef]

80. Font-Tullot, I. Climatología de España y Portugal; Ediciones Universidad de Salamanca: Salamanca, Spain, 2000.

81. Andrews, P. Owls, Caves and Fossils. Predation, Preservation and Accumulation of Small Mammañ Bones in Caves, with an Analysis of the Pleistocene Cave Faunas from Westbury-Sub-Mendip, Somerset, United Kingdom; Oxford University: Oxford, UK, 1990.

82. Pokines, J.T.; Kerbis Peterhans, J.C. Barn Owl (Tyto Alba) Taphonomy in the Negev Desert, Israel. Isr. J. Ecol. Evol. 1998, 44, 19-27. [CrossRef]

83. Palomo, L.J.; Gisbert, J.; Blanco, J.C. Atlas y Libro Rojo de Los Mamíferos Terrestres de España; Dirección General para la BiodiversidadSECEM-SECEMU: Madrid, Spain, 2007.

84. Cruz-Uribe, K. Distinguishing Hyena from Hominid Bone Accumulations. J. Field Archaeol. 1991, 18, 467-486.

85. Fosse, P. Variabilité Des Assemblages Osseux Créés Par l'hyène Des Cavernes. Paléo 1997, 9, 15-54. [CrossRef]

86. Alcaraz-Castaño, M.; Alcolea-González, J.; Kehl, M.; Albert, R.-M.; Baena-Preysler, J.; de Balbín-Behrmann, R.; Cuartero, F.; Cuenca-Bescós, G.; Jiménez-Barredo, F.; López-Sáez, J.-A.; et al. A Context for the Last Neandertals of Interior Iberia: Los Casares Cave Revisited. PLoS ONE 2017, 12, e0180823. [CrossRef] [PubMed]

87. Arsuaga, J.L.; Baquedano, E.; Pérez-González, A.; Sala, N.; Quam, R.M.; Rodríguez, L.; García, R.; García, N.; Álvarez-Lao, D.J.; Laplana, C.; et al. Understanding the Ancient Habitats of the Last-Interglacial (Late MIS 5) Neanderthals of Central Iberia: Paleoenvironmental and Taphonomic Evidence from the Cueva Del Camino (Spain) Site. Quat. Int. 2012, 275, 55-75. [CrossRef] 
88. Daura, J.; Sanz, M.; Julià, R.; García-Fernández, D.; Fornós, J.J.; Vaquero, M.; Allué, E.; López-García, J.M.; Blain, H.A.; Ortiz, J.E.; et al. Cova Del Rinoceront (Castelldefels, Barcelona): A Terrestrial Record for the Last Interglacial Period (MIS 5) in the Mediterranean Coast of the Iberian Peninsula. Quat. Sci. Rev. 2015, 114, 203-227. [CrossRef]

89. Daura, J.; Sanz, M.; Allué, E.; Vaquero, M.; López-García, J.M.; Sánchez-Marco, A.; Domènech, R.; Martinell, J.; Carrión, J.S.; Ortiz, J.E.; et al. Palaeoenvironments of the Last Neanderthals in SW Europe (MIS 3): Cova Del Coll Verdaguer (Barcelona, NE of Iberian Peninsula). Quat. Sci. Rev. 2017, 177, 34-56. [CrossRef]

90. Vaquero, M.; van der Made, J.; Blain, H.-A.; Ibáñez, N.; López-García, J.M.; Rivals, F.; Alonso, S.; Ameijenda, A.; Bennàsar, M.; Fernández-García, M.; et al. Fauna, Environment and Human Presence during MIS5 in the North of Spain: The New Site of Valdavara 3. Comptes Rendus Palevol 2018, 17, 557-593. [CrossRef]

91. Villa, P.; Soressi, M. Stone Tools in Carnivore Sites: The Case of Bois Roche. J. Anthropol. Res. 2000, 56, 187-215. [CrossRef]

92. Trinkaus, E.; Maki, J.; Zilhão, J. Middle Paleolithic Human Remains from the Gruta Da Oliveira (Torres Novas), Portugal. Am. J. Phys. Anthropol. 2007, 134, 263-273. [CrossRef]

93. Camarós, E.; Cueto, M.; Lorenzo, C.; Villaverde, V.; Rivals, F. Large Carnivore Attacks on Hominins during the Pleistocene: A Forensic Approach with a Neanderthal Example. Archaeol. Anthropol. Sci. 2016, 8, 635-646. [CrossRef]

94. Camarós, E.; Cueto, M.; Rosell, J.; Díez, J.C.; Blasco, R.; Duhig, C.; Darlas, A.; Harvati, K.; Jordá, J.; Montes, L.; et al. Hunted or Scavenged Neanderthals? Taphonomic Approach to Hominin Fossils with Carnivore Damage. Int. J. Osteoarchaeol. 2017, 27, 606-620. [CrossRef]

95. Garralda, M.D.; Giacobini, G.; Vandermeersch, B. Neanderthal Cutmarks: Combe-Grenal and Marillac (France). A SEM Analysis. Anthropologie 2005, 43, 189-198. [CrossRef]

96. Orschiedt, J. Der Fall Krapina-Neue Ergebnisse Zur Frage von Kannibalismus Beim Neandertaler. Quartär 2008, 55, 63-81.

97. Pettitt, P. The Neanderthal Dead. Before Farming 2002, 2002, 1-26. [CrossRef]

98. Arsuaga, J.L.; Villaverde, V.; Quam, R.; Martínez, I.; Carretero, J.M.; Lorenzo, C.; Gracia, A. New Neandertal Remains from Cova Negra (Valencia, Spain). J. Hum. Evol. 2007, 52, 31-58. [CrossRef]

99. Zilio, L.; Hammond, H.; Karampaglidis, T.; Sánchez-Romero, L.; Blasco, R.; Rivals, F.; Rufà, A.; Picin, A.; Chacón, M.G.; Demuro, M.; et al. Examining Neanderthal and Carnivore Occupations of Teixoneres Cave (Moià, Barcelona, Spain) Using Archaeostratigraphic and Intra-Site Spatial Analysis. Sci. Rep. 2021, 11, 4339. [CrossRef]

100. Neruda, P.; Kaminská, L. Neanderthals at the Open-Air Site of Bojnice III: The Issue of "Missing” Artifacts. In Settlement Dynamics of the Middle Paleolithic and Middle Stone Age IV.; Conard, N.J., Delagnes, A., Eds.; Diane Marie Kerns Kerns Verlag: Tübingen, Germany, 2015; pp. 205-226.

101. Picin, A.; Chacón, M.G.; Gómez de Soler, B.; Blasco, R.; Rivals, F.; Rosell, J. Neanderthal Mobile Toolkit in Short-Term Occupations at Teixoneres Cave (Moia, Spain). J. Archaeol. Sci. Rep. 2020, 29, 102165. [CrossRef]

102. Vaquero, M.; Chacon, M.G.; Garcia-Anton, M.D.; de Soler, B.G.; Martinez, K.; Cuartero, F. Time and Space in the Formation of Lithic Assemblages: The Example of Abric Romani Level. J. Quat. Int. 2012, 247, 162-181. [CrossRef]

103. Sanz-Royo, A.; Sanz, M.; Daura, J. Upper Pleistocene Equids from Terrasses de La Riera Dels Canyars (NE Iberian Peninsula): The Presence of Equus Ferus and Equus Hydruntinus Based on Dental Criteria and Their Implications for Palaeontological Identification and Palaeoenvironmental Reconstr. Quat. Int. 2020, 566-567, 78-90. [CrossRef]

104. Burke, A.; Eisenmann, V.; Ambler, G.K. The Systematic Position of Equus Hydruntinus, an Extinct Species of Pleistocene Equid. Quat. Res. 2003, 59, 459-469. [CrossRef]

105. Daura, J.; Sanz, M.; García, N.; Allué, E.; Vaquero, M.; Fierro, E.; Carrión, J.S.; López-García, J.M.; Blain, H.A.; Sánchez-Marco, A.; et al. Terrasses de La Riera Dels Canyars (Gavà, Barcelona): The Landscape of Heinrich Stadial 4 North of the "Ebro Frontier" and Implications for Modern Human Dispersal into Iberia. Quat. Sci. Rev. 2013, 60, 26-48. [CrossRef]

106. López-García, J.M.; Blain, H.-A.; Sanz, M.; Daura, J. A Coastal Reservoir of Terrestrial Resources for Neanderthal Populations in North-Eastern Iberia: Palaeoenvironmental Data Inferred from the Small-Vertebrate Assemblage of Cova Del Gegant, Sitges, Barcelona. J. Quat. Sci. 2012, 27, 105-113. [CrossRef]

107. Brugal, J.-P.; Jaubert, J. Les Gisements Paléontologiques Pléistocènes à Indices de Fréquentation Humaine: Un Nouveau Type de Comportement de Prédation? Paléo 1991, 3, 15-41. [CrossRef]

108. Sanz, M.; Daura, J. Taphonomic Analysis of an Ungulate-Dominated Accumulation at the Pleistocene Cova Del Rinoceront Site near Barcelona, Spain (Northeastern Iberian Peninsula). Palaeogeogr. Palaeoclimatol. Palaeoecol. 2018, 498, 24-38. [CrossRef]

109. Sanz, M.; Daura, J. Carnivore Involvement in Bone Assemblages Based on Taphonomic and Zooarchaeological Analyses of Cova Del Coll Verdaguer Site (Barcelona, Iberian Peninsula). Hist. Biol. 2018, 30, 807-820. [CrossRef]

110. Beyries, S.; Boëda, E. Etude Technologique et Traces d'utilisation Des “Éclats Débordants" de Corbehem (Pas-de-Calais). Bull. Société Préhistorique Français 1983, 80, 275-279. [CrossRef] 